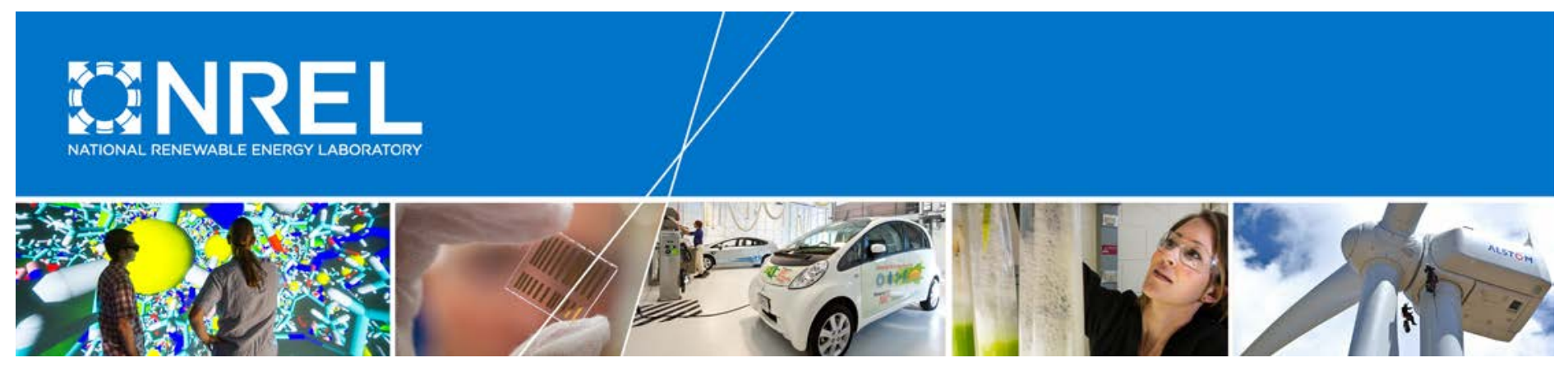

\title{
Water-Related Power Plant Curtailments: An Overview of Incidents and Contributing Factors
}

James McCall, Jordan Macknick, and Daniel Hillman National Renewable Energy Laboratory

NREL is a national laboratory of the U.S. Department of Energy Office of Energy Efficiency \& Renewable Energy Operated by the Alliance for Sustainable Energy, LLC

This report is available at no cost from the National Renewable Energy Laboratory (NREL) at www.nrel.gov/publications.

Technical Report

NREL/TP-6A20-67084

December 2016 


\section{Water-Related Power Plant Curtailments: An Overview of Incidents and Contributing Actors}

James McCall, Jordan Macknick, and Daniel Hillman National Renewable Energy Laboratory

Prepared under Task No. EPSA.Z140

NREL is a national laboratory of the U.S. Department of Energy Office of Energy Efficiency \& Renewable Energy Operated by the Alliance for Sustainable Energy, LLC

This report is available at no cost from the National Renewable Energy Laboratory (NREL) at www.nrel.gov/publications.

National Renewable Energy Laboratory 15013 Denver West Parkway Golden, CO 80401

303-275-3000 • www.nrel.gov

\section{Technical Report}

NREL/TP-6A20-67084

December 2016

Contract No. DE-AC36-08G028308 


\section{NOTICE}

This report was prepared as an account of work sponsored by an agency of the United States government. Neither the United States government nor any agency thereof, nor any of their employees, makes any warranty, express or implied, or assumes any legal liability or responsibility for the accuracy, completeness, or usefulness of any information, apparatus, product, or process disclosed, or represents that its use would not infringe privately owned rights. Reference herein to any specific commercial product, process, or service by trade name, trademark, manufacturer, or otherwise does not necessarily constitute or imply its endorsement, recommendation, or favoring by the United States government or any agency thereof. The views and opinions of authors expressed herein do not necessarily state or reflect those of the United States government or any agency thereof.

This report is available at no cost from the National Renewable Energy Laboratory (NREL) at www.nrel.gov/publications.

Available electronically at SciTech Connect http:/www.osti.gov/scitech

Available for a processing fee to U.S. Department of Energy and its contractors, in paper, from:

U.S. Department of Energy

Office of Scientific and Technical Information

P.O. Box 62

Oak Ridge, TN 37831-0062

OSTI http://www.osti.gov

Phone: 865.576.8401

Fax: 865.576.5728

Email: reports@osti.gov

Available for sale to the public, in paper, from:

U.S. Department of Commerce

National Technical Information Service

5301 Shawnee Road

Alexandria, VA 22312

NTIS http://www.ntis.gov

Phone: 800.553 .6847 or 703.605 .6000

Fax: 703.605.6900

Email: orders@ntis.gov 


\section{Abstract}

Water temperatures and water availability can affect the reliable operations of power plants in the United States. However, data on water-related impacts on the energy sector are not consolidated and are reported by multiple agencies. This study provides an overview of historical incidents where water resources have affected power plant operations, discusses the various data sources providing information, and creates a publicly available and open access database that contains consolidated information about water-related power plant curtailment and shutdown incidents. Power plants can be affected by water resources if incoming water temperatures are too high, water discharge temperatures are too high, or sufficient water is unavailable to operate. Changes in climate have the potential to exacerbate uncertainty over water resource availability and temperature. Power plant impacts from water resources include curtailment of generation, plant shutdowns, and requests for regulatory variances. In addition, many power plants have developed adaptation approaches to reducing the potential risks of water-related issues by investing in new technologies or developing and implementing contingency plans for droughts or heat waves. This study identifies 43 incidents of water-related power plant issues from 2000 to 2015 , drawing from a variety of different data sets. These incidents occur throughout the United States and affect coal and nuclear plants that use once-through, recirculating, and pond-cooling systems. In addition, water temperature violations reported to the U.S. Environmental Protection Agency are also considered, with 35 temperature violations noted from 2012 to 2015. In addition to providing some background information on incidents, this effort has also created an open access database on the Open Energy Information (Open EI) platform that contains information about water-related power plant issues that platform users can update. 


\section{Acknowledgements}

This work was supported by the U.S. Department of Energy Office of Energy Policy and Systems Analysis under Contract No. DE-AC36-08GO28308 with the National Renewable Energy Laboratory. The authors wish to thank John Agan, Judi Greenwald, Diana Bauer, Fletcher Fields, Sam Bockenauer, Jenah Zweig, Bob Rose, Joe Bryson, and Sean Ramach for their review of this work. We are also indebted to Laura Vimmerstedt, Nate Blair, Liz Doris, and David Mooney for their thoughtful comments, input, and review of the document in its various stages. We also wish to thank Mike Meshek, Jørn Aabakken and Billy Roberts for their editorial and graphics support. 


\section{Table of Contents}

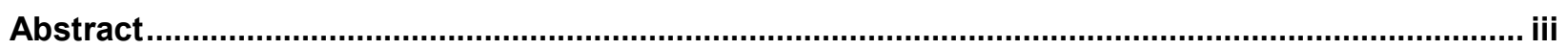

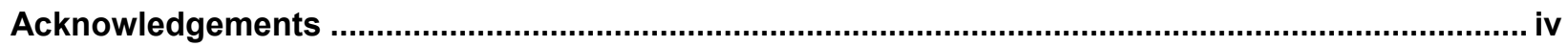

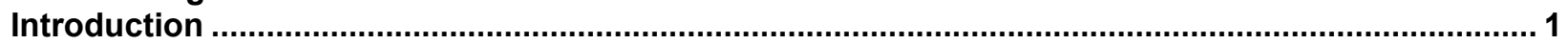

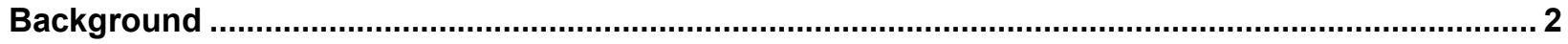

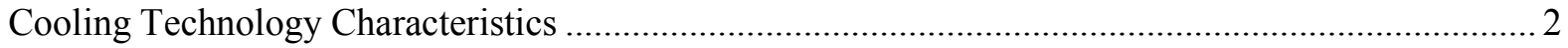

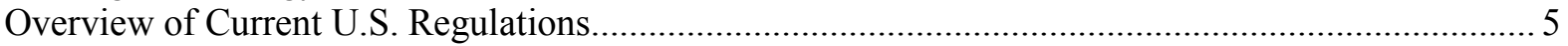

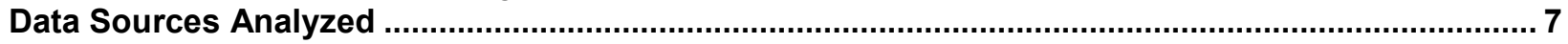

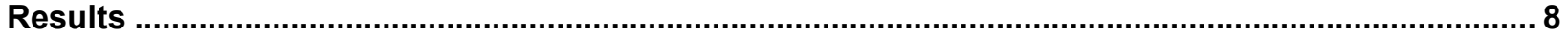

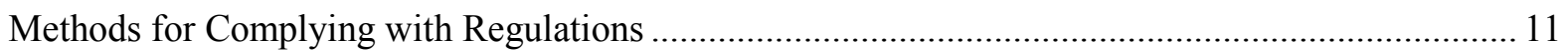

Adaptation Approaches to Preventing Future Incidents .................................................................. 11

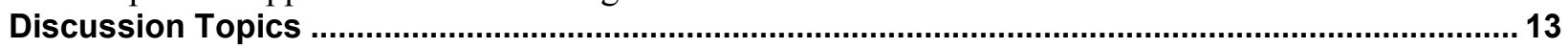

Importance of Water on Energy System Cost and Reliability....................................................... 13

Potential Impacts of Climate Change on Water and Implications for Power Sector........................... 14

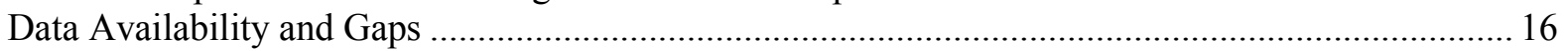

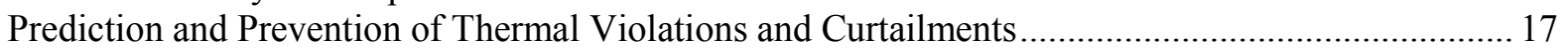

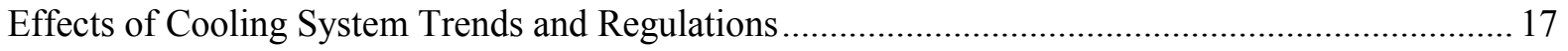

Description of Database of Historical Water-Related Power Plant Curtailments ............................... 18

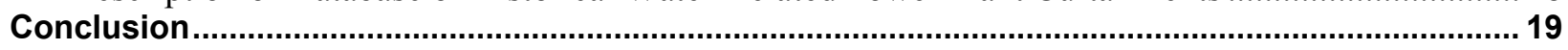

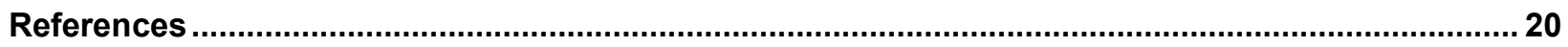

Appendix A. Reported Curtailment and Shutdown Events Data....................................................... 24

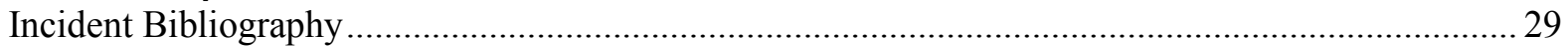

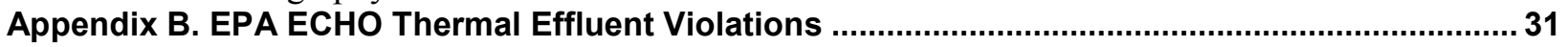




\section{List of Figures}

Figure 1. Total withdrawals for thermal electric cooling by county, 2010 (Hamilton Project 2014).......... 2

Figure 2. Water withdrawal and consumption of thermal electric generators in the United States, 2011

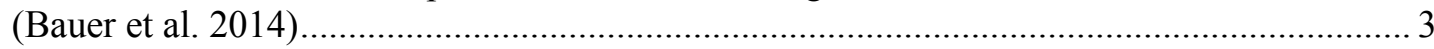

Figure 3. Water withdrawal (gal/MWh) for various generation and cooling technologies (Bauer et al.

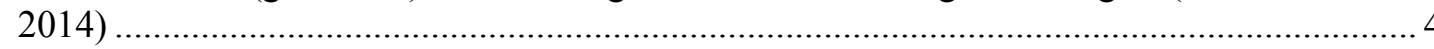

Figure 4. Water consumption (gal/MWh) for various generation and cooling technologies (Bauer et al. 2014)

Figure 5. Location and key characteristics of water-related power plant curtailments, 2000-2015 (OpenEI 2016b)

Figure 6. Location and key characteristics of NPDES violations from the EPA ECHO database, 20122015 (OpenEI 2016a)

Figure 7. Climate indicators that affect water availability (DOE 2013)

\section{List of Tables}

Table A-1. Reported Curtailment and Shutdown Events Data 24

Table B-1. Observed EPA ECHO Thermal Effluent Violations 


\section{Introduction}

Water is integral to the operations of thermal power plants. It is withdrawn from rivers, ocean, lakes, aquifers, or other non-traditional sources for cooling, fuel processing, and emissions control during electricity generation (Averyt et al. 2011; Argonne National Laboratory 2012; Macknick et al. 2012; Meldrum et al. 2013). The electricity sector's operational water use represents $41 \%$ of national freshwater withdrawals (Maupin et al. 2014), and the high water requirements and water-related dependencies have led to events where power plants have had to curtail generation or shutdown (DOE 2013; Rogers et al. 2013). Changes in climatic and hydrologic patterns could lead to greater vulnerabilities of power plants in the United States in the future (Van Vliet et al. 2012; Van Vliet et al. 2016).

Water-related issues can impact power generation via three distinct mechanisms: (1) lack of cooling water, (2) high intake water temperatures, and (3) high discharge water temperatures. Lack of cooling water can cause power generators to curtail power production or shut down completely. High temperatures of intake water can reduce plant operating efficiency, reduce maximum generation capacity, and force a generator to shut down. After water is withdrawn and used for cooling, water discharged back to a body of water that exceeds certain temperatures can cause curtailment of power or plant shutdown in order to comply with water quality standards and environmental laws.

In this paper, we examine the availability of data regarding water-related vulnerabilities of thermal power plants, and we focus on incidents where water availability and temperature impacted power generation in the United States. Identification and analysis of past issues can benchmark the regional and economic issues for power generators due to variations in water availability and temperature, as well as identify measures that effectively address and prevent future water-related vulnerabilities. With the threat of a changing climate, being able to predict how water availability and temperature variations can affect the economics and reliability of the power sector can help inform planning decisions. In addition, the availability of data can greatly influence how well regulators, industry, and researchers are informed in the planning process.

This paper is structured into four sections. The first section details background information of water usage, cooling technologies, and environmental laws and standards that impact thermal electric power generation. The second section outlines data sources that were used in data collection. The third section summarizes past findings of water impacts on power generation. The final section introduces discussion topics important to water use in the power generation sector and evaluates data needs for future research. 


\section{Background}

The thermal electric power generation sector is the largest withdrawer of water in the United States. It represents roughly $41 \%$ of total water withdrawals and around $4 \%$ of total water consumptive uses in the United States (Bauer et al. 2014; Maupin et al. 2014). Historically, most water withdrawals have been from surface water sources, which made up $94 \%$ of thermal electric water withdrawals in 2008, but this can vary by region depending on water availability (Averyt et al. 2011). Currently, the East and Midwest dominate water withdrawals for thermal electric cooling (USGS 2016). The regional water use trends and variations at a county level are shown in Figure 1.

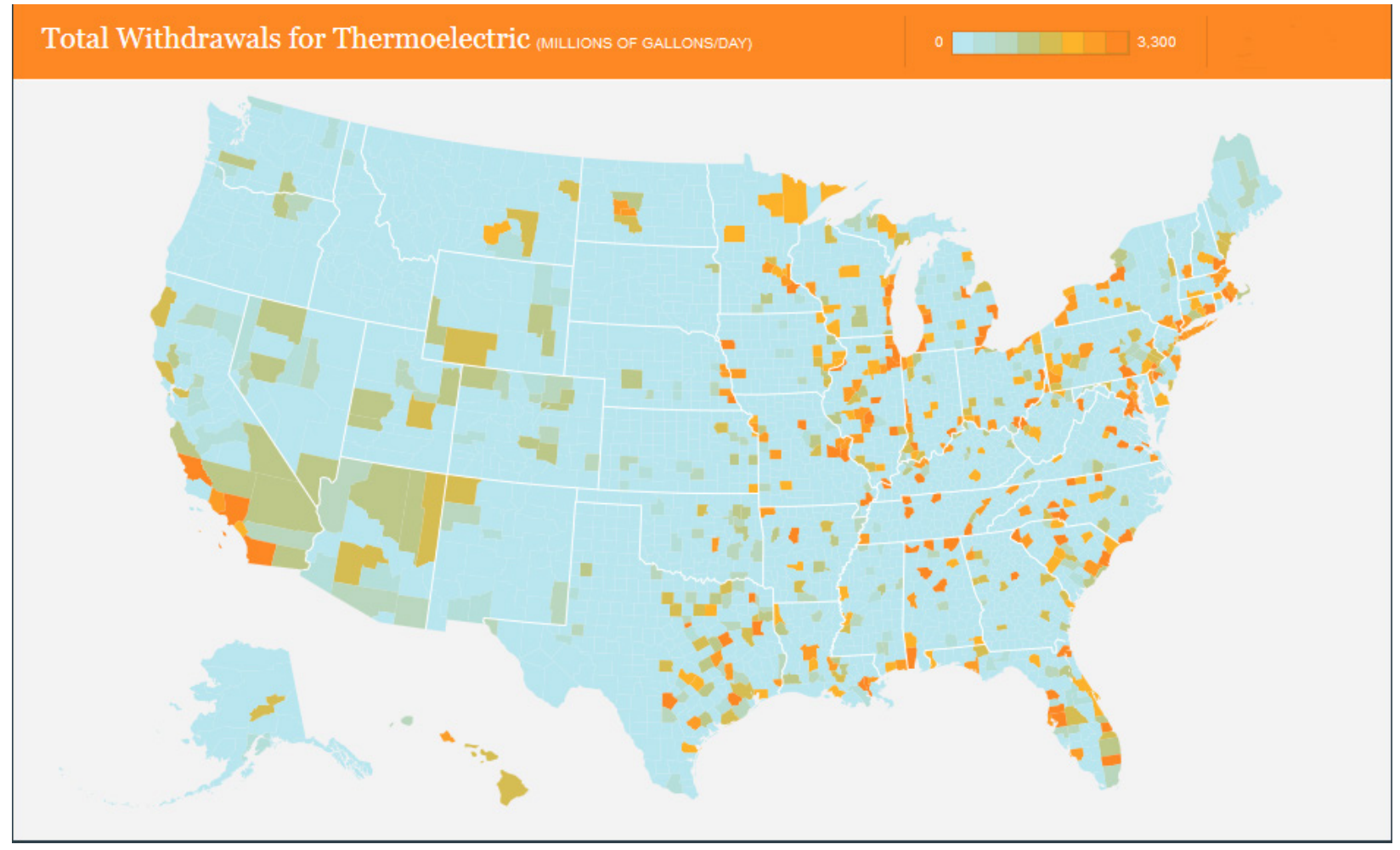

Figure 1. Total withdrawals for thermal electric cooling by county, 2010 (Hamilton Project 2014)

\section{Cooling Technology Characteristics}

Water withdrawal and consumptive uses for thermal electric generating plants depend highly on the installed cooling technology, which is generally a once-through, recirculating, or dry cooling system.

Once-through (or "open loop") cooling systems withdraw water from an ocean, river, or lake and use water to condense steam after power generation. Heat is transferred from the steam to cooling water via heat exchangers and the heated water is discharged back to the water source. For typical once-through cooling systems, water discharges are $14^{\circ} \mathrm{F}-22^{\circ} \mathrm{F}$ higher than inlet temperatures. Once-through cooling systems are considered the most efficient and least capital intensive cooling technology (GAO 2009; DOE 2010). Once-through cooling systems withdraw the most water of all cooling technologies but consume less than recirculating cooing systems as shown in Figure 2. 
Recirculating (or "closed loop") cooling systems generally use an evaporation cooling tower; however, they can also have configurations that use a cooling reservoir or pond. Water use is similar to that in once-through systems except that rather than being discharged back to the source, the withdrawn water is reused after transferring heat to the air. Recirculating systems cool steam to the wet bulb air temperature and are effective at limiting heat input into source water bodies (GAO 2009; Stewart et al. 2013). Recirculating cooling systems withdraw much less water than once-through systems, but they consume more. Recirculating cooling made up $88 \%$ of thermal electric cooling water consumption in 2011 (Bauer et al. 2014). Recirculating systems come with, on average, a $1.2 \%$ energy penalty compared with once-through systems (DeNooyer et al. 2016).

Dry cooling systems use air to cool steam rather than water. Movement of air across a cooling radiator transfers heat from the cooling fluid to the ambient air. Dry cooling systems drastically reduce both water withdrawal and consumption, but they are more costly and less efficient than other cooling technologies (Pate et al. 2007). Dry cooling systems have a $2 \%-3 \%$ parasitic energy loss, and they cost 1.5 to 8 times more than similarly sized water cooled systems (DeNooyer et al. 2016). Hybrid cooling systems use both dry cooled and recirculating technologies in the same system to optimize cooling depending on local conditions, and they can reduce water consumption 25\%-50\% compared to only wet-cooled systems (EPRI 2008).

Water withdrawal and consumption depend on the fuel source and generating technology as shown in Figure 3 and Figure 4.
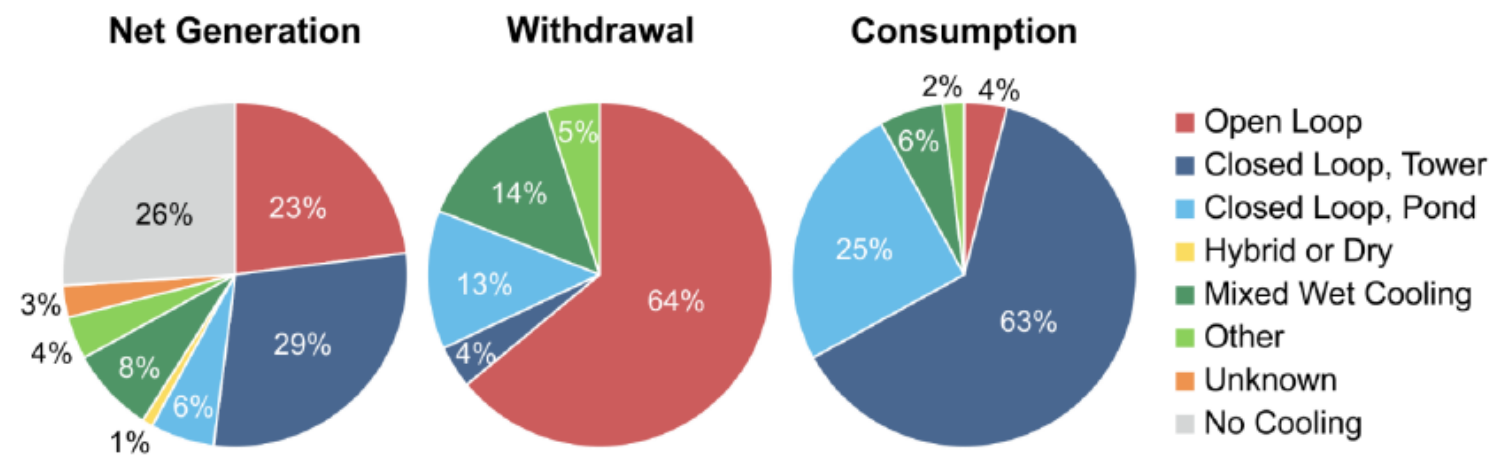

Figure 2. Water withdrawal and consumption of thermal electric generators in the United States, 2011 (Bauer et al. 2014) 


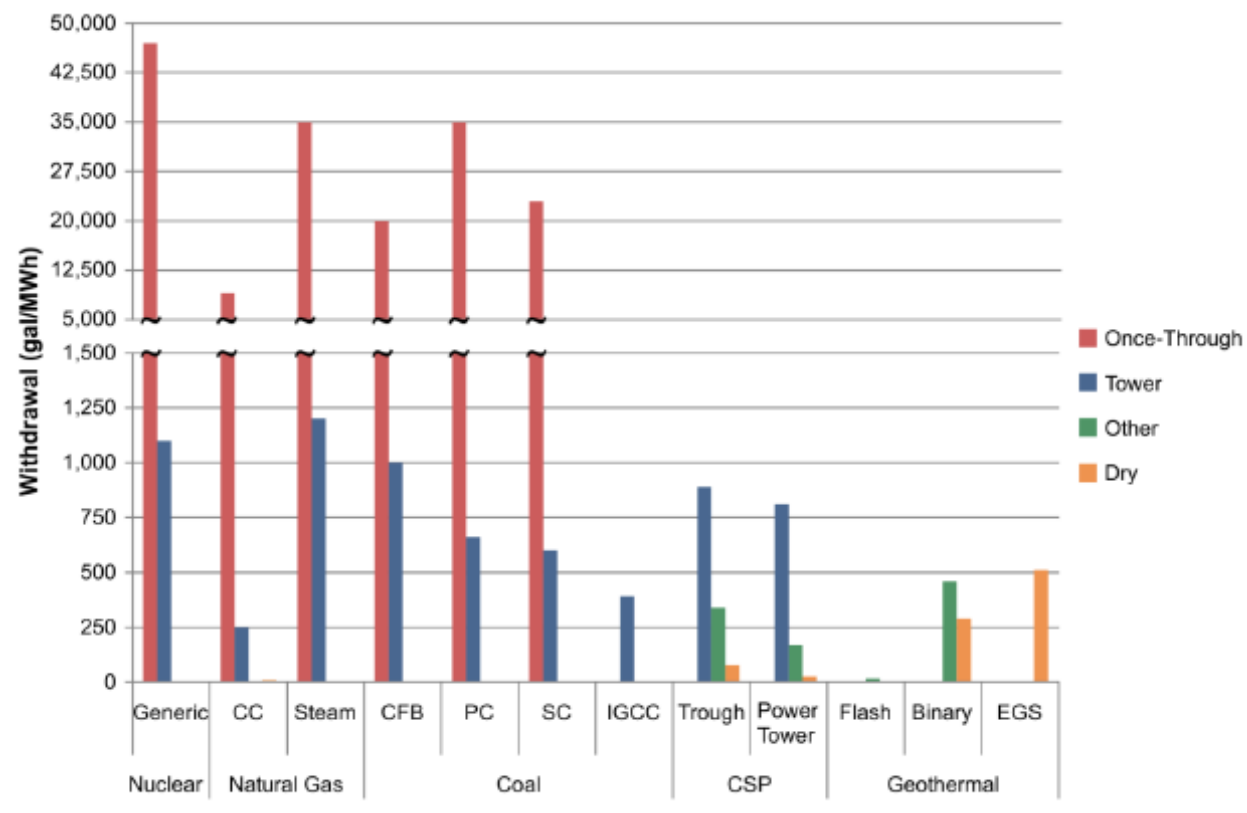

Figure 3. Water withdrawal (gal/MWh) for various generation and cooling technologies ${ }^{1}$ (Bauer et al. 2014)

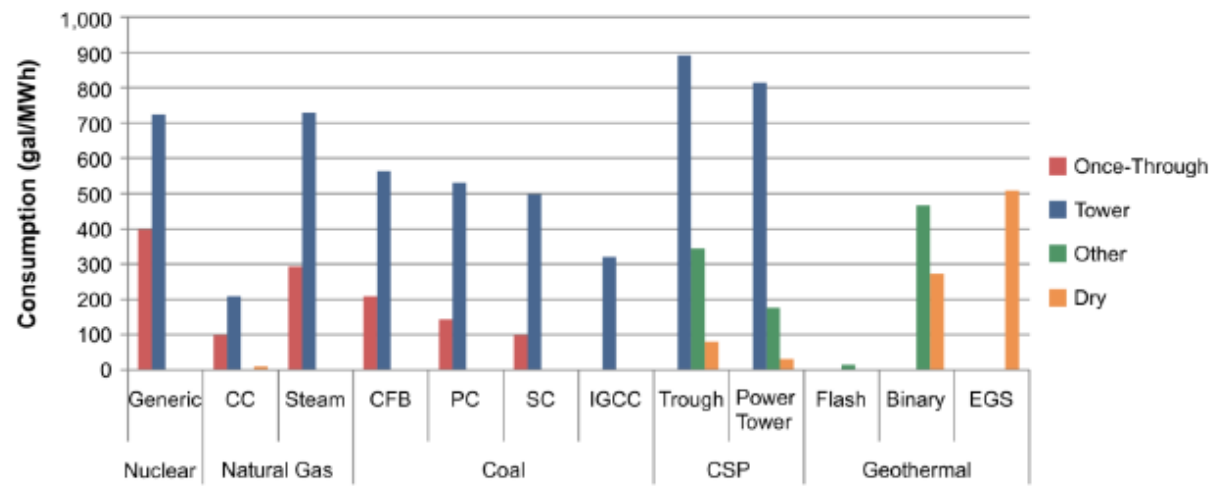

Figure 4. Water consumption (gal/MWh) for various generation and cooling technologies (Bauer et al. 2014)

\section{Contributing Factors to Cooling Technology Efficiency and Operation}

Several climatic factors can impact cooling system efficiency and operation for thermal electric generators. High air temperature limits the cooling ability and efficiency of dry cooled systems, which is compounded by higher demand for electricity when air temperature is high. For example, dry cooling efficiency losses are generally around $2 \%-3 \%$ in moderate climates but can increase to $10 \%$ in areas with high ambient air temperatures (Stillwell and Webber 2013). For gas-fired generators, high inlet air temperature decreases generation efficiency and capacity (Argonne National Laboratory 2012).

\footnotetext{
${ }^{1}$ CC: combined cycle; CFB: circulating fluidized bed; CSP: concentrating solar power; EGS: enhanced geothermal system; gal/MWh: gallons per megawatt-hour IGCC: integrated gasification combined cycle; PC: pulverized coal; SC: supercritical pulverized coal
} 
High inlet water temperature can affect efficiency and operations of thermal generators, depending on the type of fuel, prime mover, and cooling system. Every $1.8^{\circ} \mathrm{F}$ increase in water temperature can correspond to up to a $-6 \%$ in operating efficiency (Colman 2013). Higher inlet water temperatures correlate with higher discharge temperature, which may lead to unsafe operation or discharge violations (Argonne National Laboratory 2012; Rogers et al. 2013). Hightemperature water contains less dissolved oxygen than cold water and can have negative impacts on aquatic ecosystems, including fish kills in certain ecosystems and impacts on species diversity (DeNooyer et al. 2016; Averyt et al. 2011).

During drought and water shortages, thermal generator performance may be impaired even as these generators are in higher demand due to lower hydropower output. Low water levels can impact the rate of water withdrawal and cause curtailment or complete shutdown. According to Kimmel and Veil (2009), most power plant water intakes are less than 20 feet from a source water surface. In 2009, during a drought, roughly $43 \%$ of the nation's power plant's intakes were at risk of being exposed (Kimmell and Veil 2009). Decreasing water availability may lead some generators to modify intake structures to prevent inlets from being exposed. Also, shallow bodies of water are more affected by higher air temperatures, and this can lead to a rise in water temperature.

\section{Overview of Current U.S. Regulations}

The U.S. Environmental Protection Agency (EPA) regulates cooling water systems and thermal discharges under Section 316 and 402 of the Clean Water Act. Section 316(a) deals with thermal variances in National Pollution Discharge Elimination System (NPDES) permits, and Section 316(b) regulates the design and operation of cooling water intake structures. Section 402 requires NPDES permits that implement limitations to control pollutants such as thermal based upon technology and water quality standards. States and U.S. territories can apply for authority to regulate several NPDES permit categories. Currently, only Idaho, Massachusetts, New Hampshire, New Mexico, and Puerto Rico do not have authority from the EPA to administer a state NPDES program (EPA 2016b). Water quality standards and the implementing NPDES thermal effluent limitations vary by state, but they typically require that thermal discharges remain below $90^{\circ} \mathrm{F}$ (Madden, Lewis, and Davis 2013).

Section 316(a) of the Clean Water Act authorizes the permitting authority to issue less stringent permit conditions for the thermal component of discharges in lieu of the limits set out in Sections 301 and 306 of the Clean Water Act (EPA 2013). For this modification to be allowed under the Clean Water Act, an owner or operator must demonstrate to the authorized agency that the proposed effluent limitations are more stringent than what is required to assure the protection and propagation of indigenous aquatic wildlife in the body of water where the discharge occurs (EPA 2002).

Section 316(b) requires a point source to employ the location, design, construction, and capacity of cooling water intake structures that utilize the best technology available for reducing impacts to the environment (EPA 2002). EPA has promulgated a series of 316(b) regulations that are implemented through the NPDES permit program and point sources will need to update cooling water intake structures to the best available technology (BTA) before permit renewal (Tomichek, n.d.). Under the recently issued Existing Facility 316(b) regulations that apply to most power 
plants, installing a recirculating cooling system is one method of compliance with the rule, but other methods are available to operators (DOE 2010; Tomichek, n.d.).

Section 316(a) sets forth a process for generators to comply with environmental standards for thermal discharges in situations where high temperatures may lead to curtailment or a shutdown. However, this process allows more heat to be transferred to source bodies of water compared to normal water quality standards. Section $316(\mathrm{~b})$ is prescriptive on cooling water intake technology characteristics which can impact the overall withdrawal and consumption rates of the power sector. Section 316(b) does not contribute to individual curtailment events, but renewal applications submitted for NPDES permits must demonstrate compliance with section 316(b) rules. Costs associated with compliance have caused some operators to change operations or shut down. ${ }^{2}$

In addition to water-related regulations set by the EPA, the U.S. Nuclear Regulatory Commission (NRC) sets limits on inlet temperatures for safe nuclear reactor operation (Bauer et al. 2014). Maximum inlet temperatures are based on the installed cooling system and are included in an operating license.

Environmental and safety regulations set the limits for intake and discharge temperatures for thermal electric generators. Many different data sources report violations of permit requirements, incidents where curtailment occurs to stay within regulations, and where variances are needed to maintain power plant operation levels. We analyze these data sources in the next section.

\footnotetext{
${ }^{2}$ For example, the Oyster Creek Nuclear Generating Station operators decided to shut down the plant in 2019 rather than upgrading the cooling system to the best available technology (New Jersey Department of Environmental Protection 2016).
} 


\section{Data Sources Analyzed}

The United States Geological Survey (USGS) maintains the most comprehensive data set of water withdrawal across sectors in the United States. Every five years, the USGS estimates total freshwater and groundwater usage in the United States for different water use categories, including thermal electric power, irrigation, and public supply (USGS 2016). Estimates of water usage are available at the county level. The most recent data set for total U.S. water withdrawals by sector is for the year 2010 .

The Energy Information Agency (EIA) collects data on power plant operations in their Form 923 survey. For Schedule 8 of this survey, the EIA collects environmental data on a monthly basis from thermal electric facilities with a capacity of $100 \mathrm{MW}$ or more. Data are provided on a plantby-plant basis for cooling technology employed, water withdrawal, water consumption, and average and maximum water intake and discharge temperatures. The most recent data available in Form 923 is for 2014.

The EPA Enforcement and Compliance History Online (ECHO) website provides data regarding regulated facilities compliance with NPDES and other environmental quality permits. Compliance data are tied to a given facility and are reported monthly. We analyzed only facilities that were categorized as electric services (SIC code 4911) with thermal effluent violations from January 2012 through December 2015.

The NRC publishes documents in their Agencywide Documents Access and Management System (ADAMS) database. Also, operating permits authorized by the NRC are available in this database from which plant level operating temperatures can be gleaned. We analyzed documents from ADAMS that referenced regulatory thermal variances for nuclear power plants from 2010 to 2015 .

The North American Electric Reliability Corporation (NERC) collects data regarding electrical emergency incidents and disruptions in form OE-417. Severe weather incidents that cause load shedding or generation curtailment must be reported in this form. However, from analyzing OE417 data from 2002-2015, we found no severe weather events currently related to reliability issues resulting from high temperatures or water availability.

In states where the EPA has granted the states the authority of NPDES permits, state environmental protection agencies publish data regarding thermal variances and temperature violations. Each state presents this information in different areas such as environmental registers, publication databases, and discharge permits. No relevant data through review of state environmental register was used in the incident database.

Outside of these reporting databases, numerous publications, press releases, and news stories reported incidents relating to water issues. Some reports contained detailed information regarding the cause and action taken to prevent generators from being out of compliance and to improve performance and reliability. The list of these sources can be found in the Incident Bibliography in Appendix A.

The findings from our analysis of these sources - including curtailment events, shutdown events and data gaps - are presented in the next section. 


\section{Results}

Incidents where high water temperatures (intake or discharge) and/or water shortages affected power generators are documented in various data sources. Data are presented with regard to reported incidents or violations of permit conditions. Some distinct incidents are highlighted to show the range of occurrences and compliance methods. Not all data sources documented individual curtailment or shutdown events but instead focused on water risks for thermal electric generators.

From 2000 to 2015, 43 incidents were documented in reports, newspaper articles, and press releases. Of these incidents, 18 involved coal-fired power plants and 25 involved nuclear plants. Incidents are organized into four categories: intake water too warm, discharge water too warm, both intake and discharge water too warm, and lack of intake water. Of the 43 incidents, nearly half (20) were a result of the discharge water being too warm. There were eight incidents where intake water was too warm, seven incidents where both intake and discharge water was too warm, and seven cases where there was inadequate intake water volume ${ }^{3}$. In five cases, data sources identified plants that were at risk but no incident had occurred yet. Once-through cooling technologies were used in 22 of the 43 incidents. Cooling ponds were used in ten incidents, and recirculating cooling technologies were used in eight. Nearly all incidents occurred in summer months (generally July and August), and most happened during a drought, heat wave, or both. Incidents occurred throughout the United States. Figure 5 shows a map of incidents along with key crucial information about each incident. A detailed summary of the incidents can be found in Appendix A.

Analysis of EPA ECHO data found 35 incidents where discharge temperatures for electric power plants were greater than the NPDES permit limits between January 2012 and December 2015. There were no incidents that overlapped between incidents presented in literature review and EPA ECHO data analysis. Compliance limits were highly plant dependent and had different discharge temperature limits and regulations for monthly, daily, or instantaneous temperature monitoring. Some plants had consistent temperature discharge limits throughout the year, while others had different seasonal limits. Some plants had isolated incidents of noncompliance, while others had noncompliance incidents that lasted several months or were reoccurring. Violations occurred throughout the year, not only in summer, and they were spread across the United States. Figure 6 shows the location of NPDES violations from the EPA ECHO database. A summary of plant level violations in this timeframe can be found in Appendix B. The 35 incidents represent a large increase from five incidents of average monthly discharge temperature violations (four coal plants and one natural gas plant) over the previous three-year period (January 2008-December 2011), as presented in Bauer et al. 2014. However, there is no evidence to currently suggest that that this is an indication of a worsening problem and may be due to data reporting or methodological differences.

\footnotetext{
${ }^{3}$ One incident—at the Donald C. Cook nuclear plant in Michigan (see Table A-1)—resulted in a shut down when a heat wave caused air temperatures inside the containment building to be higher than the operating permit limit of $120^{\circ} \mathrm{F}$.
} 


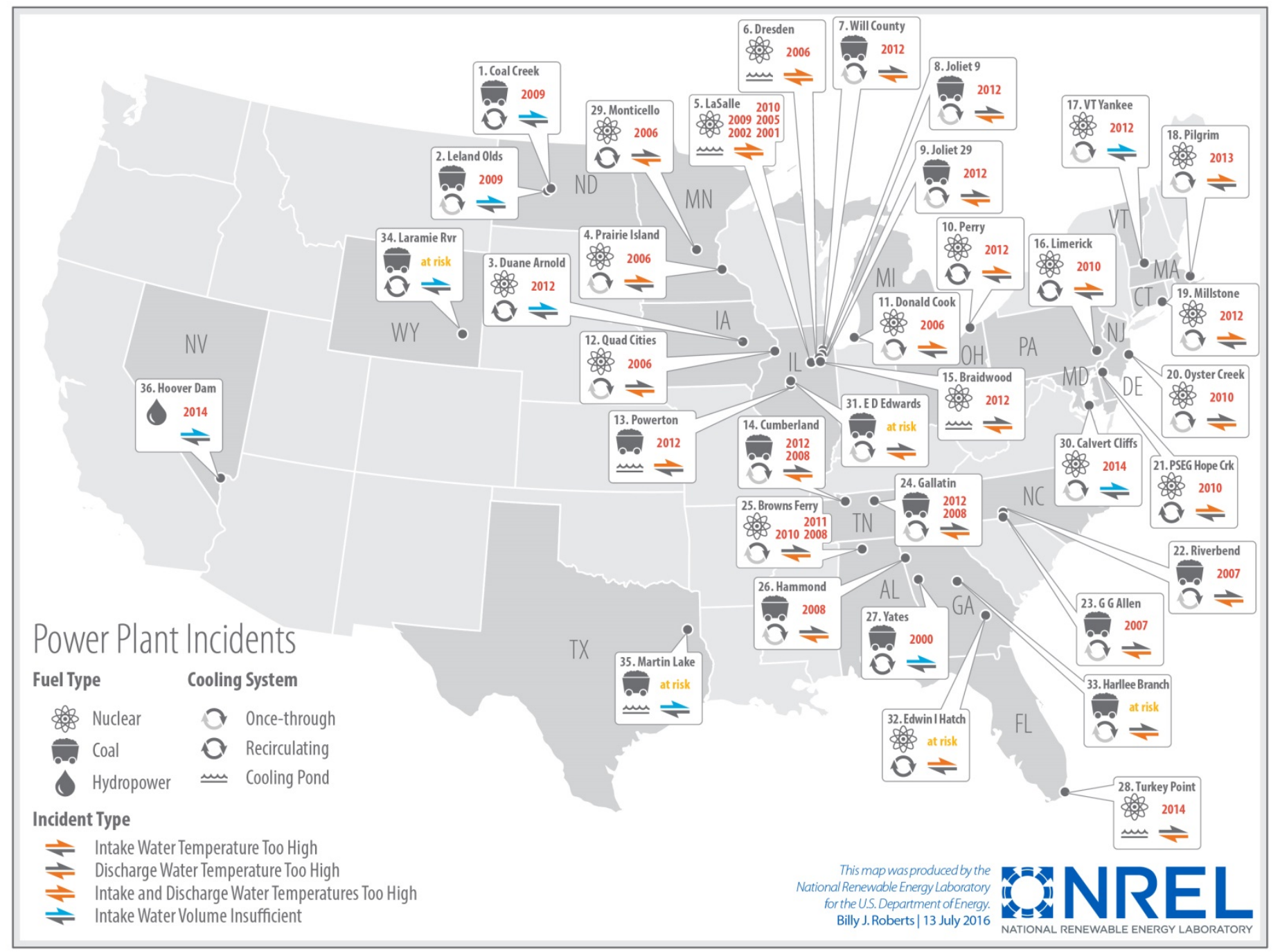

Figure 5. Location and key characteristics of water-related power plant curtailments, 2000-2015 (OpenEl 2016b) 


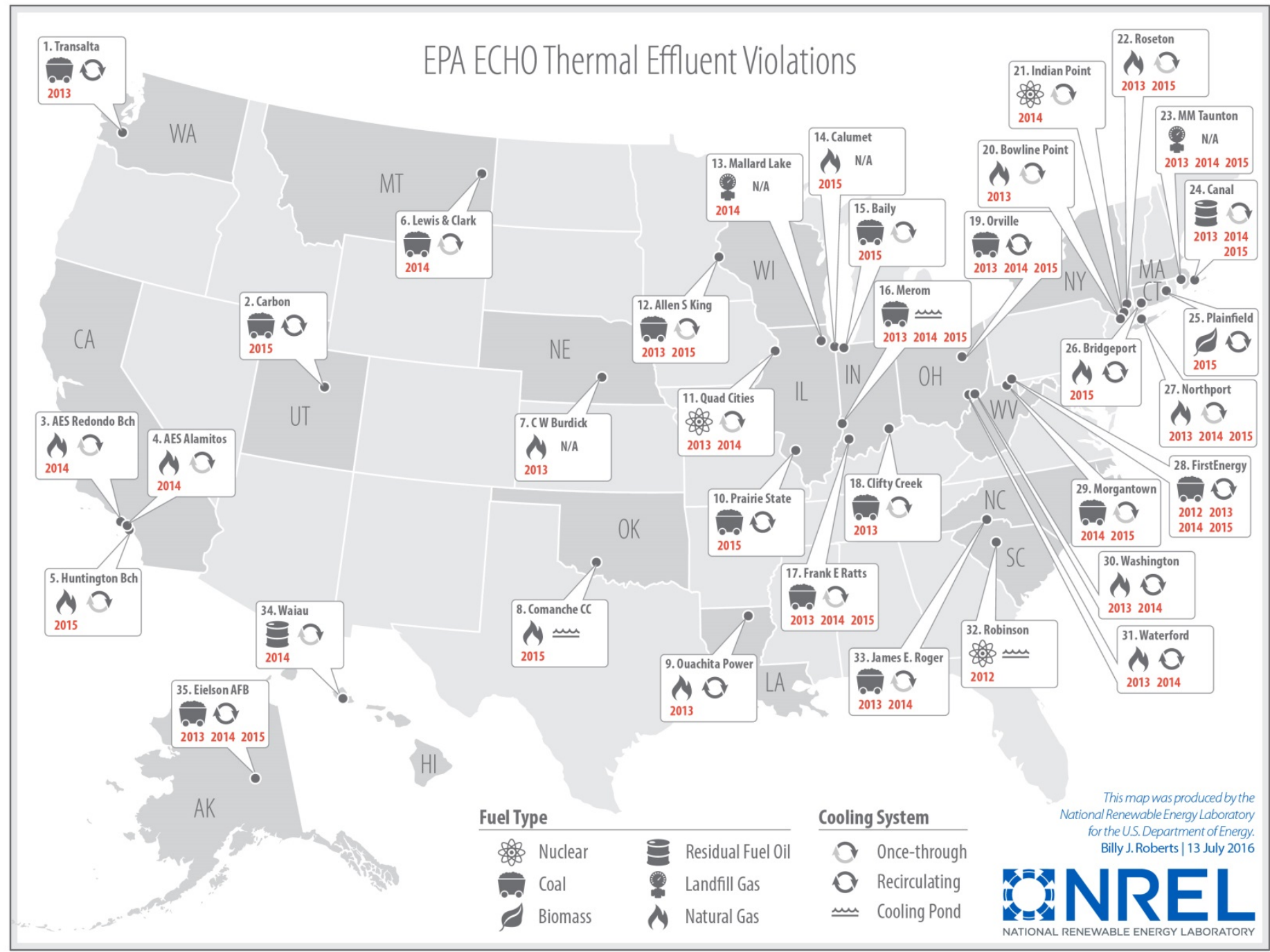

Figure 6. Location and key characteristics of NPDES violations from the EPA ECHO database, 2012-2015 (OpenEl 2016a) 
Outside of EPA ECHO reporting, the EPA performed a study on thermal effluent discharges, limitations, and variances in 1992. As of 1992, nearly one third of 580 power plants had received a thermal variance under Section 316(a) from EPA water quality standards, and a majority of these facilities had shown no impact to the environment from thermal discharges. In two facilities with active thermal variances, there was evidence of fish kill from high discharge temperatures (EPA 1992). This report also documented chronic effects on populations (e.g., reduced diversity, health effects, and change in species mix) from certain thermal discharges.

A review of the NRC ADAMS database found six documents regarding high discharge temperatures, thermal variances, and/or intake water levels between January 2010 and December 2015. Most of the incidents occurred at the peak of summer in July and all but one plant was located in Illinois (Turkey Point in Florida requested a variance from NRC for high discharge temperatures). All of these incidents are presented in Figure 5 and Appendix A.

\section{Methods for Complying with Regulations}

Three main types of actions for compliance with regulations emerged during our review of incidents: power curtailments, plant shutdowns, and the granting of a thermal variance. Allowable variances are granted by the state environmental protection agency or the EPA branch that has authority over NPDES permits. Variances are only available through a Water Quality Standard (WQS) variance or 316(a) variance implemented through issuance or modification of NPDES permits. ${ }^{4}$ For nuclear power plants, the NRC must be informed of the variance and ensure the plant is still operating within safety limits.

When variances are not available or granted, generators must curtail power to remain within discharge temperature limits. Some incidents have led to limited curtailment of output $(\sim 3 \%)$, while others have reduced generating capacity by half. Generation reduction at curtailed generators usually increases generation at power plants not affected by the water constraints, which could entail importing electricity from other balancing authorities. If generators cannot curtail to cool discharge water to remain within safety and environmental limits, a full shutdown must be instituted. For the events we examined, 17 plants curtailed power to handle high discharge temperatures, eight plants shut down, and five plants attempted to obtain a temporary relief variance to remain operational.

\section{Adaptation Approaches to Preventing Future Incidents}

Methods other than, curtailment, shutdown, or regulatory variances were used in 10 of the incidents we evaluated in order to reduce the impacts of the event as well as prevent future incidents. Note curtailment and shutdowns are all short term measures and most of the adaptation methods discussed focus on fixing long term water vulnerabilities. These adaptation approaches included building additional cooling towers, using temporary cooling towers, implementing an

\footnotetext{
${ }^{4}$ Temporary relief for power plants has been granted by some states previously, but this approach has not been allowed for compliance purposes upon further review by the EPA. As an example, Illinois granted relief to a thermal variance from NPDES permits in 2012 which was eventually not allowed by the EPA and had no effect on compliance.
} 
Extreme Heat Implementation Plan ${ }^{5}$, dredging the source river downstream of discharge, and finding new water sources.

Some adaptation methods, such as the use of cooling towers, are implemented to maintain effluent discharge temperatures within the permit limit. Two plants in the incidents reviewed built additional cooling towers to deal with high discharge temperatures. The Cumberland coal plant in Tennessee installed more cooling capacity in response to a heat wave in 2008, while the Harllee Branch coal plant in Georgia identified a risk of high discharge temperatures that prompted the installation of additional cooling towers. The Hammond coal plant in Georgia used additional portable cooling towers during heat waves in 2007 and 2008 to stay within permit limits. The LaSalle nuclear generating station in Illinois developed an Extreme Heat Implementation Plan in response to a fish kill in 2001, and it has used this plan four other times (in 2002, 2005, 2009, and 2010), according to regulatory documents. ${ }^{6}$

Other adaptation measures are in response to the scarcity of water. In 2012, the Duane Arnold nuclear plant in Iowa dredged the river upstream of the plant to ensure adequate water supply to the plant. Another plant, the Laramie River coal plant in Wyoming, changed its water intake source from surface water to irrigation water in order to maintain a reliable water source.

${ }^{5}$ The Extreme Heat Implementation Plan was specifically developed by LaSalle Generating Facility.

${ }^{6}$ For more information about these incidents, see Table A-1. 


\section{Discussion Topics}

In this section, we introduce discussion topics important to water use in the power generation sector and evaluate data needs for future research.

\section{Importance of Water on Energy System Cost and Reliability}

The resiliency of power plants to variability in water resource characteristics depends on the quantity of water required for operation, the quality of water required, and the combined availability and stability (accounts for seasonal water trends, frequency of drought, and impacts of drought) of the plant's water source (Kelic et al. 2009). High water temperatures can lead to efficiency downgrades, curtailment, and potentially shutdowns, which can cause imports of electricity from other balancing authorities and require the use of more expensive generators to meet load. Utility performance is measured based on the percentage of load met through the year, so it is in the interest of utilities to take the necessary measures to ensure they can meet loads. The North American Electricity Reliability Corporation requires that balancing authorities meet Reliability Performance Objectives to ensure a stable and resilient electrical grid. When a generator is at risk for shut down or curtailment due to water vulnerabilities, reliability must be provided by other generators, placing more burdens on utilities. During a concurrent heat wave (which increases demands) and curtailment event (which reduces supplies), there is a trade-off for regulators between maintaining system power reliability and protecting the environment. In such an event, there may be intense pressure to relax regulations to maintain reliability (Eisenack 2016).

Pechan and Eisenack (2014) found that during the 2006 heat wave in Europe, when many thermal generators were forced to curtail or shutdown, spot electricity prices were $11 \%$ higher than average electricity prices. This price increase was more pronounced during peak demand $(17 \%)$ than off peak (7\%). According to the analysis, these price increases were mostly passed on to consumers and generation costs rose only slightly (Pechan and Eisenack 2014). In the U.S., wholesale electricity prices in Texas in 2011 rose from $\$ 45 / \mathrm{MWh}$ in the morning to over $\$ 1,900 / \mathrm{MWh}$ in the afternoon on the 15 minute ahead real-time market due to high temperatures and increased electricity demand (EIA 2011).

Water shortages can lead to electricity price increases because of their impacts on hydroelectric generators and thermal generators. Hydroelectric power production is one of the least expensive sources of electricity in terms of marginal costs and generation is dependent on the availability of water resources. When water is unavailable, whether due to low reservoir levels, low streamflow, or other environmental factors, decreased hydroelectric generation must be compensated by other sources of generation that are more expensive to operate. In 2014, for example, power production at Hoover Dam was reduced due to an extended drought (Krier 2012). If other generators making up lost hydroelectric production require water for cooling, as is commonly the case, their operational efficiency could be affected by increased air and water temperatures from a drought or heat wave, thus further exacerbating cost increases. Poch et al. (2009) modeled a severe drought year for the Western Interconnection and found that due to large reductions in hydroelectric power generation and increased natural gas generation, average electricity prices increased $7 \%-34 \%$, depending on the season; impacts were more severe in the summer months and lowest in the fall (September and October) (Poch, Conzelmann, and Veselka 2009). 
Water shortages for thermal generators can lead to curtailment or shutdowns in a balancing authority, which can lead to an increase in costs to meet loads. Excess power often must be imported into the region, and this expense is often passed on to consumers; for example, in 2008, Duke Energy imported $520 \mathrm{MW}$ of power from outside its balancing authority to maintain electrical services (Sovacool 2009).

DOE (2010) found that 347 coal plants were at risk from water demand, supply constraints, or both. One third of these plants were in the Southeast, and there was an even split between recirculating and once-through cooling technologies (DOE 2010). With increased changes in precipitation and climate patterns, drought and heat wave events may become more variable and less predictable (NOAA 2013). Regions face different risks, depending on local resources and existing generation technologies; the risks in the Northwest primarily relate to hydroelectric generation while the risks in the Southwest and the East relate to the high reliance on surface water for cooling.

Along with risks to electrical reliability, a lack of price signals for both water and electricity demand. The cost of water often represents a small share of energy production costs, as (1) water prices do not reflect region-specific water conditions or methods of conveyance and (2) water prices make up a small portion operating costs at power plants compared to fuel purchases. However, changes in water quantity or quality can lead to high plant-level and system-level costs (Bauer et al. 2014). Moreover, as water represents a small share of generating costs, water reliability adaptation measures may be neglected until issues begin to affect generation. A potential solution would be to incorporate water price signals into the price of electricity, but there is currently no market mechanism available to take water scarcity and prices into account.

\section{Potential Impacts of Climate Change on Water and Implications for Power Sector}

According to recent climate modeling in the context of global energy and water systems by Van Vliet et al. (2016), the largest increases in water temperature by 2050 globally are expected in eastern North America, Europe, Asia, and Southern Africa $\left(1.3^{\circ} \mathrm{F}-2.2^{\circ} \mathrm{F}\right)$. Van Vliet et al. (2016) also found that a large part of the world would experience increased stream flows due to increased precipitation associated with rising temperatures. However, areas where most of the thermal electric generators are currently located could see a decrease in annual stream flows (Van Vliet et al. 2016). River temperatures are already increasing due to urbanization and higher air temperatures. As water flows in some regions decline, higher air temperatures will impact water temperatures more than they have in the past (Madden, Lewis, and Davis 2013).

From a U.S. perspective, DOE 2013 outlined modeled climate changes and the impact on the U.S. energy system (DOE 2013). DOE 2013 references climatic trends detailed in NOAA 2013 that show a $1.5^{\circ} \mathrm{F}$ increase in average air temperatures since the start of the $20^{\text {th }}$ century and this rate of warming has been shown to be increasing in recent decades (NOAA 2013). Along with this rise in temperatures, the frequency and duration of heat wave and drought events is expected to increase (NOAA 2013). Also, EPRI 2011 found that nearly 25\% of thermoelectric generation is projected to be in counties with moderate to high water sustainability stress in 2030 (EPRI 2011). Overall trends in U.S. climate patterns are shown in Figure 7. 


\begin{tabular}{|c|c|c|}
\hline $\begin{array}{l}\text { Climate } \\
\text { indicator }\end{array}$ & $\begin{array}{l}\text { Projected } \\
\text { change }\end{array}$ & Geographic coverage \\
\hline \multirow{2}{*}{$\begin{array}{l}\text { Annual } \\
\text { precipitation }\end{array}$} & Increasing & Northern United States \\
\hline & Decreasing & Southern United States \\
\hline $\begin{array}{l}\text { Summer } \\
\text { precipitation }\end{array}$ & Decreasing & United States \\
\hline $\begin{array}{l}\text { Proportion of } \\
\text { precipitation } \\
\text { falling as snow }\end{array}$ & Decreasing & $\begin{array}{l}\text { Northeast, Northwest, and } \\
\text { high elevations across the } \\
\text { United States }\end{array}$ \\
\hline $\begin{array}{l}\text { Mountain snow } \\
\text { water equivalent }\end{array}$ & Decreasing & Western United States \\
\hline Peak streamflow & $\begin{array}{l}\text { Occurring } \\
\text { earlier }\end{array}$ & $\begin{array}{l}\text { Western and Northeast United } \\
\text { States }\end{array}$ \\
\hline \multirow{2}{*}{$\begin{array}{l}\text { Annual runoff } \\
\text { and streamflow }\end{array}$} & Increasing & Midwest and Northeast \\
\hline & Decreasing & Southwest \\
\hline $\begin{array}{l}\text { Duration, } \\
\text { frequency, and } \\
\text { intensity of } \\
\text { droughts }\end{array}$ & Increasing & Southern United States \\
\hline
\end{tabular}

Figure 7. Climate indicators that affect water availability (DOE 2013)

Changing climate will impact efficiencies of thermal electric generators and will change demand for electricity. Higher air temperatures will lead to higher water temperatures and will reduce cooling efficiencies. Van Vliet et al. (2012) found that average summer capacities of thermal electric generators in the U.S. and Europe would decrease by $4.4 \%-16.0 \%$ in summer months, with modeled temperature increases and electricity demand (Van Vliet et al. 2012). On a regional level, Miara et al. (2013), found that projected climate conditions in the Northeast United States would reduce the amount of water available for thermoelectric cooling and result in a loss of generation of $2.5 \%$ in the Northeast over baseline climate levels (Miara et al. 2013).

Climate change affects seasonal electricity demand differently, depending on changed heating needs, cooling needs, and the extent to which heating and cooling are electrified. With climate change, the heating season has shortened and the total amount of energy for heating has decreased. Climate change has resulted in a $2^{\circ} \mathrm{F}-5^{\circ} \mathrm{F}$ increase in average spring temperatures in the United States over the $20^{\text {th }}$ century (Harto et al. 2011; NOAA 2013). Increases in average temperatures have decreased heating demand needs during the winter and spring months ${ }^{7}$. However, this historical increase in average temperatures has led to higher electricity demands for cooling in summer and fall months. In contrast, the cooling season has lengthened and the total energy used for cooling has increased, with most of the increase in electricity due to the large share of electricity for cooling (Dell et al. 2014). Often the increase in cooling needs outweighs the decrease in heating needs, leading to an overall increase in electricity demand (Coughlin 2008). Harto et al. (2011) found that reported increases in electricity demand for from an average air temperature increase of $2^{\circ} \mathrm{F}$ were $1 \%-8 \%$ higher than without an increase in average air temperature and everything else remaining constant (Harto et al. 2011).

\footnotetext{
${ }^{7}$ Almost half of U.S. homes use natural gas for heating needs compared to electricity (EIA 2015). A reduction in heating days will reduce total household energy use, but winter electricity demand will reduce less due to natural gas heating systems.
} 
Higher air temperatures have led to greater penetration of air conditioning in regions where it was previously not needed (e.g. the Northeast U.S.) (DOE 2015). This increased use of air conditioning has led to greater peak electricity demand in the summer (Coughlin 2008). The Independent System Operator-New England projects that its annual energy use may stay flat or decrease slightly between 2015 and 2024, while peak energy demand will increase by 3.3\% over that timeframe to handle cooling needs (ISO-NE 2016).

Higher air temperatures may also impact hydroelectric generators, causing evaporation rates in reservoirs and potentially leading to early snowmelt. Early snowmelt can lead to reduced summer and increased winter availability of water for electricity production, the opposite of seasonal demand (Coughlin 2008). Increased variation in precipitation patterns may cause an increase in energy usage for water transportation, and water may have to be piped or trucked to regions experiencing drought in order to meet demand (Coughlin 2008).

While climate change will impact water availability on a national level, impacts will vary on a regional level (DOE 2015). Planning for water resiliency will need to occur at both a regional and national level to reduce impacts from changes in water availability. For more information on regional strategies see DOE 2015.

\section{Data Availability and Gaps}

Studies and data collection in water usage and availability for thermal electric cooling tend to consist of periodic snapshots based on estimates and incomplete information (Bauer et al. 2014). There is no comprehensive data set that provides regular detailed information at a regional level for modeling thermal electric cooling water usage (Bauer et al. 2014).

A U.S. Government Accountability Office study (GAO 2009) found that users identified data limitations with federally available water use data. The USGS presents water usage data at the county level by sector-and according to survey respondents, it is important for comparing water usages with other sectors and statistics - but the USGS only updates this survey every five years. Also, due to budget constraints, the USGS no longer collects data on water consumption from thermal electric power plants; it only collects withdrawal data (GAO 2009). The EIA collects monthly data on water withdrawal, consumption, and cooling technology from regulated power plants over $100 \mathrm{MW}$ in capacity. USGS and EIA provide the most comprehensive data sets for water use in thermal electric cooling, but there are still limitations that impact modeling water use trends such as frequency of data updates and lack of water consumption rates.

Data regarding thermal discharge violations and non-compliance events are not collected in one readily available source. Collecting data on EPA NPDES violations currently requires a plantby-plant analysis of effluent violations for thermal discharge. The NERC OE-417 survey for electrical emergency incidents and disruptions currently has only cold or severe weather incidents and not any incidents for water temperature or availability affecting power generation. Also, curtailment incidents found in the literature and press releases for high water temperatures and droughts were not found in reported outage data from OE-417 forms.

Variances for thermal discharge limits are not currently publicly available in a centralized location. Most of these data can be found in individual state environmental registers, but a month-by-month analysis of the data is still required to find which variances were granted. NRC 
collects data on nuclear thermal variances, but accessing those variances requires an exhaustive and not readily automated search and review of the entire public document library. The EPA is in the process of compiling information on plant variances and the Electric Power Research Institute (EPRI) has a database of thermal variances and studies available for purchase. However, detailed information regarding plant variances is currently not readily and publicly available without purchase.

\section{Prediction and Prevention of Thermal Violations and Curtailments}

There is no common platform or centralized database to integrate the various data sets of water availability, water quality, climate data, and power generation into a model to predict plants at risk due to water issues (Pate et al. 2007). While some studies have identified individual plants at risk in the United States and at various regions, there is no planning model for identifying future water-related vulnerabilities in the overall power sector. Harto et al. (2011) found that areas that are accustomed to droughts are often more prepared to deal with water issues than areas with less risk for drought, yet climate change could bring new challenges to areas that have not yet been forced to confront water-related issues. Along these lines, there have not been detailed studies indicating climate thresholds that would lead to more curtailments or shutdowns of thermal generators. Numerous plant- and region-specific variables would need to be accounted for, such as intake water temperature, air temperature, wind speed, and water supply. Without long-term data and modeling, predicting incidents that can affect power system reliability will remain a challenge.

Few data sources are available regarding how water scarcity and changes in water temperature have historically affected overall power system operations, reliability, and costs. To date, only a few studies have looked at operational and electricity costs from heat waves and droughts for select regions. Results have shown historical increases in electricity prices of $7 \%-17 \%$ (Pechan and Eisenack 2014), yet these are only in certain locations and do not necessarily provide a good guide of future risks or costs, as utilities and many power plants can adapt to changing conditions.

\section{Effects of Cooling System Trends and Regulations}

Before 1970, thermal electric generators were primary built with once-through cooling systems. After 1970, primarily recirculating cooling systems were built (EIA 2014). In recent years, some plants have used dry cooling technologies, but these are mainly installed on natural gas generators (EIA 2014). The trend from once-through cooling to recirculating systems has caused water withdrawals per unit of electricity produced in the power sector to decrease, but the technology consumes more water. Also, recirculating cooling systems do not transfer heat to discharge water bodies and can keep downstream surface water temperatures from rising.

Section 316(b) of the Clean Water Act calls for thermal electric generators to install the best available cooling technology to limit environmental impacts from thermal discharges. The EPA's Section 316(b) regulations suggest installation of recirculating cooling systems for new and existing power plants as one method of compliance (EPA 2016a). Installing a recirculating cooling system could lead to decreasing water withdrawal rates for an individual generator, but could increase consumption, depending on the types of generators (Macknick et al. 2012). The amount of increased water consumption from recirculating systems compared with once-through 
systems can vary greatly, especially when increased evaporation from surface water temperature increases are accounted for with once through cooling systems (Diehl et al. 2013). Depending on local water availability and demand characteristics, tradeoffs between decreased water withdrawals and increased water consumption can have positive or negative regional impacts on water resources. Recirculating cooling technologies have historically been affected by elevated water intake temperatures as well as low water intake volumes, the impacts of which could increase in frequency or intensity with changes in climate (DOE 2013).

Some studies have recommended using alternative water sources such as ocean water, water from coal-bed methane operations, saline groundwater aquifers, and "produced water" and gas operations (DOE 2010). However, even these alternative sources may decrease the overall system cooling efficiency and not be in compliance with Section 316(b) (GAO 2009).

\section{Description of Database of Historical Water-Related Power Plant Curtailments}

Data collected from this study have been made available for public use on the Open Energy Information (OpenEI) platform (OpenEI 2016b). Public data are made freely accessible and are consolidated in one location. The structure of OpenEI allows for user-initiated contributions to the list of water-related power plant curtailments and shutdowns as they arise. This database can be used by researchers and policymakers wishing to understand historical challenges the power sector has faced related to water resources, and it can serve as the foundation for future modeling efforts to predict future vulnerabilities, evaluate stressed water conditions, or plan future generation.

\footnotetext{
${ }^{8}$ Produced water is water that is produced with oil and gas production and is generally considered a waste stream.
} 


\section{Conclusion}

In this paper, we provide an overview of the availability of data for water-related power plant curtailments and shutdowns. Drawing upon multiple sources, including peer-reviewed literature, press releases, as well as required federal and state reports, this effort provides insight into the different ways in which power plants can be vulnerable to water resource adequacy as well as the types of data available for analyzing these vulnerabilities. The effort identifies 42 incidents from 2000 to 2015 that highlight the diversity of ways in which U.S. power plants are affected by water temperatures and the availability of water. In addition, water temperature violations reported to the U.S. Environmental Protection Agency are also considered, with 35 thermal effluent violations noted from 2012 to 2015 (EPA 2016a). These incidents occurred throughout the United States and affect power plants using once-through, recirculating, and pond-cooling systems. These incidents were then documented in an open source database (Open Energy Information) that will allow users to add future incidents. This will provide a centralized place to access information on incidents on water vulnerabilities of thermoelectric power plants.

As climate changes lead to more variability in water availability, water quality characteristics, and higher electricity demands, curtailment and shutdown incidents could increase. Importantly, the power sector has adapted to changes in water resources, through both regulatory and technological mechanisms, which could dampen any potential increase in curtailment and shutdown incidents. Although water costs are generally a small piece of operational power plant costs, they can quickly escalate if water resources are not reliable.

This work accumulates available data sources and previous analyses into one source to inform future data and modeling needs. Providing information on past incidents can inform researchers and regulators on conditions that may impact water availability and quality in the future. Accurate models can help predict areas of water concern in the future and inform planning efforts in the future. Regional and national planning efforts that take into account future water availability, water needs, and electricity can allow for greater resiliency of the electrical power system. 


\section{References}

Argonne National Laboratory. 2012. "Impacts of Long-Term Drought on Power Systems in the U.S. Southwest."

Averyt, Kristen, Jeremy Fisher, Annette Huber-Lee, Aurana Lewis, Jordan Macknick, Nadia Madden, John Rogers, and Stacy Tellinghuisen. 2011. "Freshwater Use by US Power Plants: Electricity's Thirst for a Precious Resource."

Bauer, Diana, Mary Philbrick, Bob Vallario, Hoyt Battey, Zachary Clement, Fletcher Fields, and Jennifer Li. 2014. "The Water-Energy Nexus: Challenges and Opportunities." U.S. Department of Energy.

Colman, Jesse. 2013. "The Effect of Ambient Air and Water Temperature on Power Plant Efficiency.” http://dukespace.lib.duke.edu/dspace/handle/10161/6895.

Coughlin, Katie. 2008. "Physical Impacts of Climate Change on the Western US Electricity System: A Scoping Study.” Lawrence Berkeley National Laboratory.

Dell, J, S Tierney, G Franco, R Newell, R Richels, J Weyant, and T Milbank. 2014. "2014: Ch. 4: Energy Supply and Use. Climate Change Impacts in the United States: The Third National Climate Assessment." U.S. Global Change Research Program.

DeNooyer, Tyler A, Joshua M Peschel, Zhenxing Zhang, and Ashlynn S Stillwell. 2016. "Integrating Water Resources and Power Generation: The Energy-water Nexus in Illinois." Applied Energy 162: 363-71.

Diehl, T.H, M.A. Harris, J.C. Murphy, S.S. Hutson, and D.E Ladd. 2013. "Methods for Estimating Water Consumption for Thermoelectric Power Plants in the United States: U.S. Geological Survey Scientific Investigations Report 2013-5188." http://dx.doi.org/10.3133/sir20135188.

DOE. 2010. "Water Vulnerabilities for Existing Coal-Fired Power Plants.” DOE/NETL$2010 / 1429$.

_. 2013. "U.S. Energy Sector Vulnerabilities to Climate Change and Extreme Weather." http://energy.gov/downloads/us-energy-sector-vulnerabilities-climate-change-and-extremeweather.

- 2015. "Climate Change and the U.S. Energy Sector: Regional Vulnerabilities and Resilience Solutions." http://energy.gov/epsa/downloads/climate-change-and-us-energy-sectorregional-vulnerabilities-and-resilience-solutions.

EIA. 2011. "Texas Heat Wave, August 2011: Nature and Effects of an Electricity Supply Shortage - Today in Energy." September 9.

http://www.eia.gov/todayinenergy/detail.php?id=3010. 
- 2014. "Many Newer Power Plants Have Cooling Systems That Reuse Water." February 11. http://www.eia.gov/todayinenergy/detail.cfm?id=14971.

- 2015. "Household Heating Costs Are Expected to Be Lower than Previous Two Winters - Today in Energy." October 6. http://www.eia.gov/todayinenergy/detail.php?id=23232.

Eisenack, Klaus. 2016. "Institutional Adaptation to Cooling Water Scarcity for Thermoelectric Power Generation under Global Warming.” Ecological Economics 124: 153-63.

EPA. 1992. "Review of Water Quality Standards, Permit Limitations, and Variances for Thermal Discharges at Power Plants."

- 2002. "Clean Water Act."

—. 2013. "EPA Oversight Addresses Thermal Variance and Cooling Water Permit Deficiencies But Needs to Address Compliance With Public Notice Requirements."

—. 2016a. "Enforcement and Compliance History Online.” https://echo.epa.gov/.

- 2016b. "NPDES State Program Information | National Pollutant Discharge Elimination System (NPDES).” February 19. https:/www.epa.gov/npdes/npdes-state-program-information.

EPRI. 2008. "Water Use for Electric Power Generation.”

- 2011. "Water Use for Electricity Generation and Other Sectors: Recent Changes (19852005) and Future Projections (2005-2030)."

GAO. 2009. "Improvements to Federal Water Use Data Would Increase Understanding of Trends in Power Plant Water Use." GAO-10-23. Report to the Chairman, Committee on Science and Technology, House of Representatives.

Harto, CB, YE Yan, YK Demissie, D Elcock, VC Tidwell, K Hallett, J Macknick, MS Wigmosta, and TK Tesfa. 2011. "Analysis of Drought Impacts on Electricity Production in the Western and Texas Interconnections of the United States.” ANL/EVS/R-11/14. Argonne National Laboratory (ANL).

ISO-NE. 2016. “2016 Regional Electricity Outlook.” www.iso-ne.com/reo.

Kelic, Andjelka, Verne Loose, Vanessa Vargas, and Eric Vugrin. 2009. "Energy and Water Sector Policy Strategies for Drought Mitigation.”

Kimmell, TA, and JA Veil. 2009. "Impact of Drought on US Steam Electric Power Plant Cooling Water Intakes and Related Water Resource Management Issues.” Argonne National Laboratory (ANL).

Macknick, J., R. Newmark, G. Heath, and K. C. Hallett. 2012. “Operational Water Consumption and Withdrawal Factors for Electricity Generating Technologies: A Review of Existing Literature." Environmental Research Letters 7 (4): 45802. doi:10.1088/1748-9326/7/4/045802. 
Madden, N, A Lewis, and M Davis. 2013. "Thermal Effluent from the Power Sector: An Analysis of Once-through Cooling System Impacts on Surface Water Temperature."

Environmental Research Letters 8 (3): 35006.

Maupin, Molly A., Joan F. Kenny, Susan S. Hutson, John K. Lovelace, Nancy L. Barber, and Kristin S. Linsey. 2014. "Estimated Use of Water in the United States in 2010." Circular 1405. Reston, VA: U.S. Geological Survey. http://pubs.usgs.gov/circ/1405/pdf/circ1405.pdf.

Meldrum, J., S. Nettles-Anderson, G. Heath, and J. Macknick. 2013. "Life Cycle Water Use for Electricity Generation: A Review and Harmonization of Literature Estimates." Environmental Research Letters 8 (1): 15031. doi:10.1088/1748-9326/8/1/015031.

Miara, Ariel, Charles J Vörösmarty, Robert J Stewart, Wilfred M Wollheim, and Bernice Rosenzweig. 2013. "Riverine Ecosystem Services and the Thermoelectric Sector: Strategic Issues Facing the Northeastern United States.” Environmental Research Letters 8 (2): 25017.

New Jersey Department of Environmental Protection. 2016. "Comprehensive Plan of Action Item \#1: Close Oyster Creek Nuclear Power Plant.” June 16. http://www.nj.gov/dep/barnegatbay/plan-oystercreek.htm.

NOAA. 2013. "Regional Climate Trends and Scenarios for the U.S. National Climate Assessment Part 9. Climate of the Contiguous United States." http://www.nesdis.noaa.gov/technical_reports/142_Climate_Scenarios.html.

OpenEI. 2016a. "EPA ECHO Thermal Effluent Violations | Open Energy Information." http://en.openei.org/wiki/EPA_ECHO_Thermal_Effluent_Violations.

_. 2016b. "Powerplant Curtailments | Open Energy Information." http://en.openei.org/wiki/Powerplant_Curtailments.

Pate, Ron, Mike Hightower, Chris Cameron, and Wayne Einfeld. 2007. "Overview of EnergyWater Interdependencies and the Emerging Energy Demands on Water Resources." Report SAND 1349.

Pechan, Anna, and Klaus Eisenack. 2014. "The Impact of Heat Waves on Electricity Spot Markets." Energy Economics 43: 63-71.

Poch, L, G Conzelmann, and T Veselka. 2009. "An Analysis of the Effects of Drought Conditions on Electric Power Generation in the Western United States." DOE NETL Rept 2009_ 1365 .

Rogers, John, K Averyt, S Clemmer, M Davis, F Flores-Lopez, P Frumhoff, D Kenney, J Macknick, N Madden, and J Meldrum. 2013. "Water-Smart Power: Strengthening the US Electricity System in a Warming World." Union of Concerned Scientists, Cambridge, MA.

Sovacool, Benjamin K. 2009. "Running on Empty: The Electricity-Water Nexus and the US Electric Utility Sector.” Energy LJ 30: 11. 
Stewart, Robert J, Wilfred M Wollheim, Ariel Miara, Charles J Vörösmarty, Balazs Fekete, Richard B Lammers, and Bernice Rosenzweig. 2013. "Horizontal Cooling Towers: Riverine Ecosystem Services and the Fate of Thermoelectric Heat in the Contemporary Northeast US." Environmental Research Letters 8 (2): 25010.

Stillwell, Ashlynn S, and Michael E Webber. 2013. "Novel Methodology for Evaluating Economic Feasibility of Low-Water Cooling Technology Retrofits at Power Plants." Water Policy 15 (2): 292-308.

The Hamilton Project. 2014. “County Water Use Map.” November 7. http://www.hamiltonproject.org/charts/county_water_use_map/.

Tomichek, Christine. n.d. "Summary of EPAs Final 316b Rule for Cooling Water." www.kleinschmidtgroup.com/index.php/download_file/880/1/.

USGS. 2016. "Total Water Use in the United States.” May 2.

http://water.usgs.gov/watuse/wuto.html.

Van Vliet, Michelle TH, David Wiberg, Sylvain Leduc, and Keywan Riahi. 2016. "PowerGeneration System Vulnerability and Adaptation to Changes in Climate and Water Resources." Nature Climate Change.

Van Vliet, Michelle TH, John R Yearsley, Fulco Ludwig, Stefan Vögele, Dennis P Lettenmaier, and Pavel Kabat. 2012. "Vulnerability of US and European Electricity Supply to Climate Change." Nature Climate Change 2 (9): 676-81. 


\section{Appendix A. Reported Curtailment and Shutdown Events Data}

Table A-1. Reported Curtailment and Shutdown Events Data

\begin{tabular}{|c|c|c|c|c|c|c|c|c|c|c|c|}
\hline Map \# & EIA Name & Fuel & Reason & $\begin{array}{l}\text { Incident } \\
\text { Date }\end{array}$ & Resolution & $\begin{array}{l}\text { Resolution } \\
\text { Detail }\end{array}$ & $\begin{array}{l}\text { Reported } \\
\text { State }\end{array}$ & Opened & $\begin{array}{l}\text { Reported } \\
\text { Cooling } \\
\text { System }\end{array}$ & $\begin{array}{l}\text { Reported } \\
\text { Weather } \\
\text { Event }\end{array}$ & Source \\
\hline 1 & Coal Creek & Coal & $\begin{array}{l}\text { Inadequate } \\
\text { water intake } \\
\text { volume }\end{array}$ & $3 / 26 / 2009$ & Shutdown & $\begin{array}{l}\text { U.S. Army } \\
\text { Corps of } \\
\text { Engineers had } \\
\text { to shut off } \\
\text { water releases } \\
\text { at dam to } \\
\text { reduce } \\
\text { pressure from } \\
\text { ice buildup. }\end{array}$ & ND & 1979 & Recirculating & Cold snap & Gehring 2009 \\
\hline 2 & Leland Olds & Coal & $\begin{array}{l}\text { Inadequate } \\
\text { water intake } \\
\text { volume }\end{array}$ & $3 / 26 / 2009$ & Shutdown & $\begin{array}{l}\text { U.S. Army } \\
\text { Corps of } \\
\text { Engineers had } \\
\text { to shut off } \\
\text { water releases } \\
\text { at dam to } \\
\text { reduce } \\
\text { pressure from } \\
\text { ice buildup. }\end{array}$ & ND & 1966 & Once-through & Cold snap & Gehring 2009 \\
\hline 3 & $\begin{array}{l}\text { Duane } \\
\text { Arnold } \\
\text { Energy } \\
\text { Center }\end{array}$ & Nuclear & $\begin{array}{l}\text { Inadequate } \\
\text { water intake } \\
\text { volume }\end{array}$ & $8 / 9 / 2012$ & Other & $\begin{array}{l}\text { Dredged river } \\
\text { downstream }\end{array}$ & IA & 1974 & Recirculating & Heat wave & DeWitte 2012 \\
\hline 4 & $\begin{array}{l}\text { Prairie } \\
\text { Island }\end{array}$ & Nuclear & $\begin{array}{l}\text { Intake water } \\
\text { temperature }\end{array}$ & $7 / 29 / 2006$ & Curtailment & $\begin{array}{l}\text { Power output } \\
\text { derated }\end{array}$ & $\mathrm{MN}$ & 1974 & Once-Through & Heat wave & Krier 2012 \\
\hline 5 & $\begin{array}{l}\text { LaSalle } \\
\text { Generating } \\
\text { Station }\end{array}$ & Nuclear & $\begin{array}{l}\text { Intake/discharge } \\
\text { water } \\
\text { temperature }\end{array}$ & 2001 & Other & $\begin{array}{l}\text { Developed } \\
\text { Extreme Heat } \\
\text { Implementation } \\
\text { Plan }\end{array}$ & IL & 1984 & Cooling Pond & - & $\begin{array}{l}\text { ADAMS } \\
\text { ML012330070 }\end{array}$ \\
\hline 5 & $\begin{array}{l}\text { LaSalle } \\
\text { Generating } \\
\text { Station }\end{array}$ & Nuclear & $\begin{array}{l}\text { Intake/discharge } \\
\text { water } \\
\text { temperature }\end{array}$ & 2002 & Other & $\begin{array}{l}\text { Followed } \\
\text { Extreme Heat } \\
\text { Implementation } \\
\text { Plan }\end{array}$ & IL & 1984 & Cooling Pond & - & $\begin{array}{l}\text { ADAMS } \\
\text { ML15023A459 }\end{array}$ \\
\hline 5 & $\begin{array}{l}\text { LaSalle } \\
\text { Generating } \\
\text { Station }\end{array}$ & Nuclear & $\begin{array}{l}\text { Intake/discharge } \\
\text { water } \\
\text { temperature }\end{array}$ & 2005 & Other & $\begin{array}{l}\text { Followed } \\
\text { Extreme Heat } \\
\text { Implementation } \\
\text { Plan }\end{array}$ & IL & 1984 & Cooling Pond & - & $\begin{array}{l}\text { ADAMS } \\
\text { ML052200481 }\end{array}$ \\
\hline
\end{tabular}




\begin{tabular}{|c|c|c|c|c|c|c|c|c|c|c|c|}
\hline Map \# & EIA Name & Fuel & Reason & $\begin{array}{l}\text { Incident } \\
\text { Date }\end{array}$ & Resolution & $\begin{array}{l}\text { Resolution } \\
\text { Detail }\end{array}$ & $\begin{array}{l}\text { Reported } \\
\text { State }\end{array}$ & Opened & $\begin{array}{l}\text { Reported } \\
\text { Cooling } \\
\text { System }\end{array}$ & $\begin{array}{l}\text { Reported } \\
\text { Weather } \\
\text { Event }\end{array}$ & Source \\
\hline 5 & $\begin{array}{l}\text { LaSalle } \\
\text { Generating } \\
\text { Station }\end{array}$ & Nuclear & $\begin{array}{l}\text { Intake/discharge } \\
\text { water } \\
\text { temperature }\end{array}$ & 2009 & Other & $\begin{array}{l}\text { Followed } \\
\text { Extreme Heat } \\
\text { Implementation } \\
\text { Plan }\end{array}$ & IL & 1984 & Cooling Pond & - & $\begin{array}{l}\text { ADAMS } \\
\text { ML092040381 }\end{array}$ \\
\hline 5 & $\begin{array}{l}\text { LaSalle } \\
\text { Generating } \\
\text { Station }\end{array}$ & Nuclear & $\begin{array}{l}\text { Intake/discharge } \\
\text { water } \\
\text { temperature }\end{array}$ & $8 / 12 / 2010$ & Other & $\begin{array}{l}\text { Followed } \\
\text { Extreme Heat } \\
\text { Implementation } \\
\text { Plan }\end{array}$ & IL & 1984 & Cooling Pond & - & $\begin{array}{l}\text { ADAMS } \\
\text { ML102371289 }\end{array}$ \\
\hline 6 & $\begin{array}{l}\text { Dresden } \\
\text { Generating } \\
\text { Station }\end{array}$ & Nuclear & $\begin{array}{l}\text { Intake/discharge } \\
\text { water } \\
\text { temperature }\end{array}$ & $7 / 29 / 2006$ & Curtailment & $\begin{array}{l}\text { Reduced } \\
\text { capacity }\end{array}$ & IL & 1970 & Cooling Pond & $\begin{array}{l}\text { Drought, } \\
\text { heat wave }\end{array}$ & Krier 2012 \\
\hline 7 & Will County & Coal & $\begin{array}{l}\text { Discharge water } \\
\text { temperature }\end{array}$ & $7 / 5 / 2012$ & Variance & $\begin{array}{l}\text { IL EPA } \\
\text { attempted } \\
\text { variance to } \\
\text { NPDES to } \\
\text { discharge at } \\
\text { high } \\
\text { temperature. }\end{array}$ & IL & 1963 & Once-Through & heat wave & $\begin{array}{l}\text { Illinois } \\
\text { Environmental } \\
\text { Protection Agency } \\
2012\end{array}$ \\
\hline 8 & Joliet 9 & Coal & $\begin{array}{l}\text { Discharge water } \\
\text { temperature }\end{array}$ & $7 / 1 / 2012$ & Variance & $\begin{array}{l}\text { IL EPA } \\
\text { attempted } \\
\text { variance to } \\
\text { NPDES to } \\
\text { discharge at } \\
\text { high } \\
\text { temperature. }\end{array}$ & IL & 1959 & Once-Through & - & $\begin{array}{l}\text { Illinois } \\
\text { Environmental } \\
\text { Protection Agency } \\
2012\end{array}$ \\
\hline 9 & Joliet 29 & Coal & $\begin{array}{l}\text { Discharge water } \\
\text { temperature }\end{array}$ & $7 / 1 / 2012$ & Variance & $\begin{array}{l}\text { IL EPA } \\
\text { attempted } \\
\text { variance to } \\
\text { NPDES to } \\
\text { discharge at } \\
\text { high } \\
\text { temperature. }\end{array}$ & IL & 1965 & Once-Through & - & $\begin{array}{l}\text { Illinois } \\
\text { Environmental } \\
\text { Protection Agency } \\
2012\end{array}$ \\
\hline 10 & Perry & Nuclear & $\begin{array}{l}\text { Intake water } \\
\text { temperature }\end{array}$ & $7 / 26 / 2012$ & Curtailment & $\begin{array}{l}\text { Power output } \\
\text { derated }\end{array}$ & $\mathrm{OH}$ & 1987 & Recirculating & Heat wave & Krier 2012 \\
\hline 11 & $\begin{array}{l}\text { Donald C. } \\
\text { Cook }\end{array}$ & Nuclear & $\begin{array}{l}\text { Air temperature } \\
\text { too warm inside } \\
\text { containment } \\
\text { building }\end{array}$ & $7 / 30 / 2006$ & Shutdown & $\begin{array}{l}\text { Shut down until } \\
\text { temperature } \\
\text { inside } \\
\text { containment } \\
\text { building was } \\
\text { less than } \\
120^{\circ} \mathrm{F}\end{array}$ & $\mathrm{Ml}$ & 1975 & Once-through & Heat Wave & Krier 2012 \\
\hline
\end{tabular}




\begin{tabular}{|c|c|c|c|c|c|c|c|c|c|c|c|}
\hline Map \# & EIA Name & Fuel & Reason & $\begin{array}{l}\text { Incident } \\
\text { Date }\end{array}$ & Resolution & $\begin{array}{l}\text { Resolution } \\
\text { Detail }\end{array}$ & $\begin{array}{l}\text { Reported } \\
\text { State }\end{array}$ & Opened & $\begin{array}{l}\text { Reported } \\
\text { Cooling } \\
\text { System }\end{array}$ & $\begin{array}{l}\text { Reported } \\
\text { Weather } \\
\text { Event }\end{array}$ & Source \\
\hline 12 & $\begin{array}{l}\text { Quad Cities } \\
\text { Generating } \\
\text { Station }\end{array}$ & Nuclear & $\begin{array}{l}\text { Discharge water } \\
\text { temperature }\end{array}$ & $7 / 29 / 2006$ & Curtailment & $\begin{array}{l}\text { Power output } \\
\text { derated }\end{array}$ & IL & 1972 & Once-Through & Heat wave & Krier 2012 \\
\hline 13 & Powerton & Coal & $\begin{array}{l}\text { Intake water } \\
\text { temperature }\end{array}$ & $7 / 10 / 2012$ & Shutdown & $\begin{array}{l}\text { Power output } \\
\text { derated, unit } \\
\text { eventually } \\
\text { shutdown }\end{array}$ & IL & 1972 & Cooling Pond & Heat wave & Bruch 2012 \\
\hline 14 & Cumberland & Coal & $\begin{array}{l}\text { Discharge water } \\
\text { temperature }\end{array}$ & 2008 & Other & $\begin{array}{l}\text { Built extra } \\
\text { cooling towers }\end{array}$ & TN & 1973 & Once-Through & Heat wave & $\begin{array}{l}\text { Army Corps of } \\
\text { Engineers } 2009\end{array}$ \\
\hline 14 & Cumberland & Coal & $\begin{array}{l}\text { Discharge water } \\
\text { temperature }\end{array}$ & 2012 & Curtailment & - & TN & 1973 & Once-Through & Heat wave & $\begin{array}{l}\text { Union of Concerned } \\
\text { Scientists } 2013 b\end{array}$ \\
\hline 15 & $\begin{array}{l}\text { Braidwood } \\
\text { Generation } \\
\text { Station }\end{array}$ & Nuclear & $\begin{array}{l}\text { Discharge water } \\
\text { temperature }\end{array}$ & $7 / 1 / 2012$ & Variance & $\begin{array}{l}\text { Variance } \\
\text { offered to } \\
\text { operate at } \\
102^{\circ} \mathrm{F} \text { outlet }\end{array}$ & IL & 1986 & Cooling Pond & $\begin{array}{l}\text { Drought, } \\
\text { heat wave }\end{array}$ & Wald 2012 \\
\hline 16 & Limerick & Nuclear & $\begin{array}{l}\text { Intake water } \\
\text { temperature }\end{array}$ & 2010 & Curtailment & $\begin{array}{l}\text { Power output } \\
\text { derated }\end{array}$ & PA & 1986 & Recirculating & Heat wave & $\begin{array}{l}\text { Wise International } \\
2013\end{array}$ \\
\hline 17 & $\begin{array}{l}\text { Vermont } \\
\text { Yankee }\end{array}$ & Nuclear & $\begin{array}{l}\text { Inadequate } \\
\text { water intake } \\
\text { volume }\end{array}$ & $7 / 12 / 2012$ & Curtailment & $\begin{array}{l}\text { Power output } \\
\text { derated }\end{array}$ & VT & 1972 & Once-Through & Drought & Krier 2012 \\
\hline 18 & Pilgrim & Nuclear & $\begin{array}{l}\text { Intake water } \\
\text { temperature }\end{array}$ & $7 / 20 / 2013$ & Curtailment & $\begin{array}{l}\text { Curtailment } \\
\text { until source } \\
\text { water was } \\
\text { under } 75^{\circ} \mathrm{F}\end{array}$ & MA & 1972 & Once-Through & Heat wave & Clemmer 2013 \\
\hline 19 & Millstone & Nuclear & $\begin{array}{l}\text { Intake water } \\
\text { temperature }\end{array}$ & $8 / 14 / 2012$ & Shutdown & $\begin{array}{l}\text { Shut down one } \\
\text { of two reactors, } \\
\text { requested } \\
\text { future variance }\end{array}$ & CT & 1975 & Once-Through & $\begin{array}{l}\text { Drought, } \\
\text { heat wave }\end{array}$ & $\begin{array}{l}\text { Wise International } \\
2013\end{array}$ \\
\hline 20 & $\begin{array}{l}\text { Oyster } \\
\text { Creek }\end{array}$ & Nuclear & $\begin{array}{l}\text { Compliance with } \\
\text { Clean Water Act } \\
\text { Section 316(b) }\end{array}$ & $12 / 9 / 2010$ & Shutdown & $\begin{array}{l}\text { Plant will shut } \\
\text { down in } 2019 \\
\text { to comply with } \\
\text { Section } 316(b) \\
\text { regulations. }\end{array}$ & $\mathrm{NJ}$ & 1954 & Once-Through & - & $\begin{array}{l}\text { New Jersey } \\
\text { Department of } \\
\text { Environmental } \\
\text { Protection } 2010\end{array}$ \\
\hline 21 & $\begin{array}{l}\text { PSEG Hope } \\
\text { Creek } \\
\text { Generating } \\
\text { Station }\end{array}$ & Nuclear & $\begin{array}{l}\text { Intake water } \\
\text { temperature }\end{array}$ & 2010 & Curtailment & $\begin{array}{l}\text { Power output } \\
\text { derated }\end{array}$ & $\mathrm{NJ}$ & 1986 & Recirculating & Heat wave & $\begin{array}{l}\text { Wise International } \\
2013\end{array}$ \\
\hline
\end{tabular}




\begin{tabular}{|c|c|c|c|c|c|c|c|c|c|c|c|}
\hline Map \# & EIA Name & Fuel & Reason & $\begin{array}{l}\text { Incident } \\
\text { Date }\end{array}$ & Resolution & $\begin{array}{l}\text { Resolution } \\
\text { Detail }\end{array}$ & $\begin{array}{l}\text { Reported } \\
\text { State }\end{array}$ & Opened & $\begin{array}{l}\text { Reported } \\
\text { Cooling } \\
\text { System }\end{array}$ & $\begin{array}{l}\text { Reported } \\
\text { Weather } \\
\text { Event }\end{array}$ & Source \\
\hline 22 & Riverbend & Coal & $\begin{array}{l}\text { Discharge water } \\
\text { temperature }\end{array}$ & $8 / 12 / 2007$ & Curtailment & - & $\mathrm{NC}$ & 1929 & Once-Through & $\begin{array}{l}\text { Drought, } \\
\text { heat wave }\end{array}$ & DOE 2013 \\
\hline 23 & G G Allen & Coal & $\begin{array}{l}\text { Discharge water } \\
\text { temperature }\end{array}$ & $8 / 12 / 2007$ & Curtailment & - & $\mathrm{NC}$ & 1957 & Once-Through & $\begin{array}{l}\text { Drought, } \\
\text { heat wave }\end{array}$ & $\begin{array}{l}\text { Union of Concerned } \\
\text { Scientists } 2013\end{array}$ \\
\hline 24 & Gallatin & Coal & $\begin{array}{l}\text { Discharge water } \\
\text { temperature }\end{array}$ & 2008 & Curtailment & $\begin{array}{l}\text { Reduced } \\
\text { output 3\% }\end{array}$ & $\mathrm{MO}$ & 1959 & None & Heat wave & $\begin{array}{l}\text { Union of Concerned } \\
\text { Scientists } 2013 b\end{array}$ \\
\hline 24 & Gallatin & Coal & $\begin{array}{l}\text { Discharge water } \\
\text { temperature }\end{array}$ & 2012 & Curtailment & - & $\mathrm{MO}$ & 1959 & None & Heat wave & $\begin{array}{l}\text { Union of Concerned } \\
\text { Scientists } 2013 b\end{array}$ \\
\hline 25 & $\begin{array}{l}\text { Browns } \\
\text { Ferry }\end{array}$ & Nuclear & $\begin{array}{l}\text { Discharge water } \\
\text { temperature }\end{array}$ & $8 / 5 / 2008$ & Shutdown & $\begin{array}{l}\text { Reduced } \\
\text { capacity by } \\
50 \%\end{array}$ & $\mathrm{AL}$ & 1977 & Once-Through & Drought & Krier 2012 \\
\hline 25 & $\begin{array}{l}\text { Browns } \\
\text { Ferry }\end{array}$ & Nuclear & $\begin{array}{l}\text { Discharge water } \\
\text { temperature }\end{array}$ & $8 / 1 / 2010$ & Curtailment & $\begin{array}{l}\text { Reduced } \\
\text { capacity by } \\
50 \%\end{array}$ & $\mathrm{AL}$ & 1977 & Once-Through & Heat wave & $\begin{array}{l}\text { Times Free Press } \\
2010\end{array}$ \\
\hline 25 & $\begin{array}{l}\text { Browns } \\
\text { Ferry }\end{array}$ & Nuclear & $\begin{array}{l}\text { Discharge water } \\
\text { temperature }\end{array}$ & $8 / 1 / 2011$ & Curtailment & $\begin{array}{l}\text { Reduced } \\
\text { capacity by } \\
50 \%\end{array}$ & $\mathrm{AL}$ & 1977 & Once-Through & Heat wave & Krier 2012 \\
\hline 26 & Hammond & Coal & $\begin{array}{l}\text { Discharge water } \\
\text { temperature }\end{array}$ & $2007-2008$ & Other & $\begin{array}{l}\text { Utilized } \\
\text { portable } \\
\text { cooling towers } \\
\text { to discharge }\end{array}$ & GA & 1954 & Once-Through & Heat wave & $\begin{array}{l}\text { Union of Concerned } \\
\text { Scientists } 2013\end{array}$ \\
\hline 27 & Yates & Coal & $\begin{array}{l}\text { Inadequate } \\
\text { water intake } \\
\text { volume }\end{array}$ & $8 / 1 / 2000$ & Curtailment & - & GA & 1974 & Recirculating & Drought & McGee 2000 \\
\hline 28 & Turkey Point & Nuclear & $\begin{array}{l}\text { Discharge water } \\
\text { temperature }\end{array}$ & $7 / 20 / 2014$ & Variance & $\begin{array}{l}\text { Upper limit set } \\
\text { to } 103^{\circ} \mathrm{F} \text { from } \\
100^{\circ} \mathrm{F} \text {, treated } \\
\text { canal for algae } \\
\text { growth }\end{array}$ & $\mathrm{FL}$ & - & - & $\begin{array}{l}\text { Above } \\
\text { average } \\
\text { temperatures }\end{array}$ & $\begin{array}{l}\text { ADAMS } \\
\text { ML15314A515 }\end{array}$ \\
\hline 29 & Monticello & Nuclear & $\begin{array}{l}\text { Discharge water } \\
\text { temperature }\end{array}$ & $7 / 29 / 2006$ & Curtailment & $\begin{array}{l}\text { Power output } \\
\text { derated }\end{array}$ & MN & 1971 & Recirculating & Heat wave & Krier 2012 \\
\hline
\end{tabular}




\begin{tabular}{|c|c|c|c|c|c|c|c|c|c|c|c|}
\hline Map \# & EIA Name & Fuel & Reason & $\begin{array}{l}\text { Incident } \\
\text { Date }\end{array}$ & Resolution & $\begin{array}{l}\text { Resolution } \\
\text { Detail }\end{array}$ & $\begin{array}{l}\text { Reported } \\
\text { State }\end{array}$ & Opened & $\begin{array}{l}\text { Reported } \\
\text { Cooling } \\
\text { System }\end{array}$ & $\begin{array}{l}\text { Reported } \\
\text { Weather } \\
\text { Event }\end{array}$ & Source \\
\hline 30 & Calvert Cliffs & Nuclear & $\begin{array}{l}\text { Inadequate } \\
\text { water intake } \\
\text { volume }\end{array}$ & $1 / 21 / 2014$ & Shutdown & $\begin{array}{l}\text { Shut down until } \\
\text { snow and ice } \\
\text { could be } \\
\text { removed from } \\
\text { intake }\end{array}$ & MD & 1975 & Once-Through & Cold Snap & Smith Hopkins 2014 \\
\hline 31 & $\begin{array}{l}\text { E D } \\
\text { Edwards }\end{array}$ & Coal & $\begin{array}{l}\text { Discharge water } \\
\text { temperature }\end{array}$ & At Risk ${ }^{9}$ & - & - & IL & 1960 & Once-Through & - & $\begin{array}{l}\text { Union of Concerned } \\
\text { Scientists } 2013 b\end{array}$ \\
\hline 32 & $\begin{array}{l}\text { Edwin I } \\
\text { Hatch }\end{array}$ & Nuclear & $\begin{array}{l}\text { Intake water } \\
\text { temperature }\end{array}$ & At Risk & - & - & GA & 1975 & Recirculating & - & $\begin{array}{l}\text { Union of Concerned } \\
\text { Scientists } 2013 b\end{array}$ \\
\hline 33 & $\begin{array}{l}\text { Harllee } \\
\text { Branch }\end{array}$ & Coal & $\begin{array}{l}\text { Discharge water } \\
\text { temperature }\end{array}$ & At Risk & Other & $\begin{array}{l}\text { Built extra } \\
\text { cooling towers }\end{array}$ & GA & 1969 & Once-Through & - & $\begin{array}{l}\text { Rome News } \\
\text { Tribune } 1997\end{array}$ \\
\hline 34 & $\begin{array}{l}\text { Laramie } \\
\text { River } \\
\text { Station } \\
\end{array}$ & Coal & $\begin{array}{l}\text { Inadequate } \\
\text { water intake } \\
\text { volume }\end{array}$ & At Risk & Other & $\begin{array}{l}\text { Changed to } \\
\text { irrigation } \\
\text { district water }\end{array}$ & WY & 1981 & Recirculating & Drought & $\begin{array}{l}\text { Union of Concerned } \\
\text { Scientists } 2011\end{array}$ \\
\hline 36 & Hoover Dam & Hydro & $\begin{array}{l}\text { Inadequate } \\
\text { water intake } \\
\text { volume }\end{array}$ & $6 / 1 / 2014$ & Shutdown & $\begin{array}{l}\text { Power output } \\
\text { derated }\end{array}$ & $A Z$ & 1936 & None & Drought & Kuckro 2014 \\
\hline
\end{tabular}

\footnotetext{
9 "At Risk" indicates that no event impacted power production, but the plant either was found to be at risk of an event or took measures to address risk.
} 


\section{Incident Bibliography}

Argonne National Laboratory. 2012. Impacts of Long-Term Drought on Power Systems in the U.S. Southwest.

Bruch, Thomas. 2012. "Dead Fish Did Not Cause Powerton Shutdown." Prairie State Outdoors. August 8.

http://www.prairiestateoutdoors.com/pso/article/dead_fish_did_not_cause_powerton_shutdown.

Clemer, Steve. 2013b. "Energy-Water Collisions: A Shared Concern for State Utility

Regulators." Union of Concerned Scientists (UCS). July 30. http://blog.ucsusa.org/steve-

clemmer/state-utility-regulators-share-concern-for-energy-water-collisions-

193? ga $=1.239891395 .1750629502 .1463505880$.

DeWitte, Dave. 2012. "Palo Nuclear Plant Operator Eyeing Cedar River Levels Cautiously."

The Gazette. http://www.thegazette.com/2012/08/09/palo-nuclear-plant-operator-eyeing-cedarriver-levels-cautiously.

DOE (U.S. Department of Energy). 2013. "U.S. Energy Sector Vulnerabilities to Climate Change and Extreme Weather." http://energy.gov/downloads/us-energy-sector-vulnerabilitiesclimate-change-and-extreme-weather.

Gehring, Brian. 2009. "Plants Along the River Shut Down." Bismarck Tribune. March 26. http://bismarcktribune.com/news/local/plants-along-the-river-shut-down/article_5e4b5540-2862$\underline{\text { 5aaa-9cf9-546866395419.html. }}$

IL EPA. 2012. "Illinois EPA Grants Midwest Generation Joliet Station 9, Joliet Station 29, and Will County Station Provisional Variance from Discharge Requirements." July 5. http://www3.illinois.gov/PressReleases/ShowPressRelease.cfm?SubjectID=29\& $\underline{\text { RecNum=10364. }}$.

Kimmell, Todd A., and John A. Veil. 2009. Impact of Drought on U.S. Steam Electric Power Plant Cooling Water Intakes and Related Water Resource Management Issues. Argonne IL: Argonne National Laboratory. DOE/NETL-2009/1364.

Krier, Robert. 2012. "Extreme Heat, Drought Show Vulnerability of Nuclear Power Plants." InsideClimate News. August 15. http://insideclimatenews.org/news/20120815/nuclear-powerplants-energy-nrc-drought-weather-heat-water.

Kuckro, Rod. 2014. "Receding Lake Mead Poses Challenges to Hoover Dam's Power Output." EnergyWire. June 30. http://www.eenews.net/stories/1060002129.

McGee, Joshua. 2000. "Drought in US Southeast Provokes Power Plant Cutbacks - Oil \& Gas Journal." Oil and Gas Journal. August 2. http://www.ogj.com/articles/2000/08/drought-in-ussoutheast-provokes-power-plant-cutbacks.html.

NRC (U.S. Nuclear Regulatory Commission). 2016. "ADAMS Public Documents." http://www.nrc.gov/reading-rm/adams.html. 
Rome News-Tribune. 1997. "Utility to Cool Water.” February.

https://news.google.com/newspapers?id=I_1MAAAAIBAJ\&sjid=nDMDAAAAIBAJ\&pg=6778, $\underline{1606811 \& h l=e n}$.

Smith Hopkins, Jamies. 2014. "Nuclear Regulators Send Inspectors to Calvert Cliffs." The Baltimore Sun. January 27. http://articles.baltimoresun.com/2014-01-27/business/bs-bzcalvert-cliffs-reactors-running-20140127___calvert-cliffs-kory-raftery-constellation-energynuclear-group.

Sohn, Paul. 2011. "River Temperature Forces Nuclear Plant to 50 Percent Power." Times Free Press. August 4. http://www.timesfreepress.com/news/news/story/2011/aug/04/rivertemperature-forces-plant-to-50-percent/55574/.

Times Free Press. 2010. "Hot River Forces Costly Cutback for TVA | Times Free Press.” August 23. http://www.timesfreepress.com/news/news/story/2010/aug/23/hot-river-forces-costlycutback-tva/27261/.

Union of Concerned Scientists. 2007. "Got Water?"

http://www.ucsusa.org/nuclear_power/nuclear_power_technology/got-water-nuclearpower.html\#.V1c-OHovZR8.

—. 2011. "Power and Water at Risk." June. http://www.ucsusa.org/clean_energy/ourenergy-choices/energy-and-water-use/power-and-water-at-risk.html\#.V1c DHovZR8.

—. 2012. “UCS EW3 Energy-Water Database V.1.3.” http://www.ucsusa.org/ew3database.

—. 2013a. "Water Dependence Risks for America's Aging Coal Fleet.” April. http://www.ucsusa.org/clean_energy/our-energy-choices/energy-and-water-use/coal-plantswater-use-risks.html\#.V1dBAnovZR8.

U.S. Army Corps of Engineers. 2009. "Managing Our Water Retention Systems.” Nashville, TN. http://www.ussdams.com/proceedings/2009Proc/1517-1532.pdf.

Wagman, David. 2013. "Water Issues Challenge Power Generators.” POWER. July 1. http://www.powermag.com/water-issues-challenge-power-generators/.

Wald, Matthew. 2012a. "So, How Hot Was It? The New York Times." The New York Times. July 17. http://green.blogs.nytimes.com/2012/07/17/so-how-hot-was-it/.

_ 2012b. "Heat Shuts Down a Coastal Reactor - The New York Times." The New York Times. August 13. http://green.blogs.nytimes.com/2012/08/13/heat-shuts-down-a-coastalreactor/.

Wise International. 2013. "Climate Change, Water and Energy." October 24. https://www.wiseinternational.org/node/4149. 


\section{Appendix B. EPA ECHO Thermal Effluent Violations}

Table B-1. Observed EPA ECHO Thermal Effluent Violations

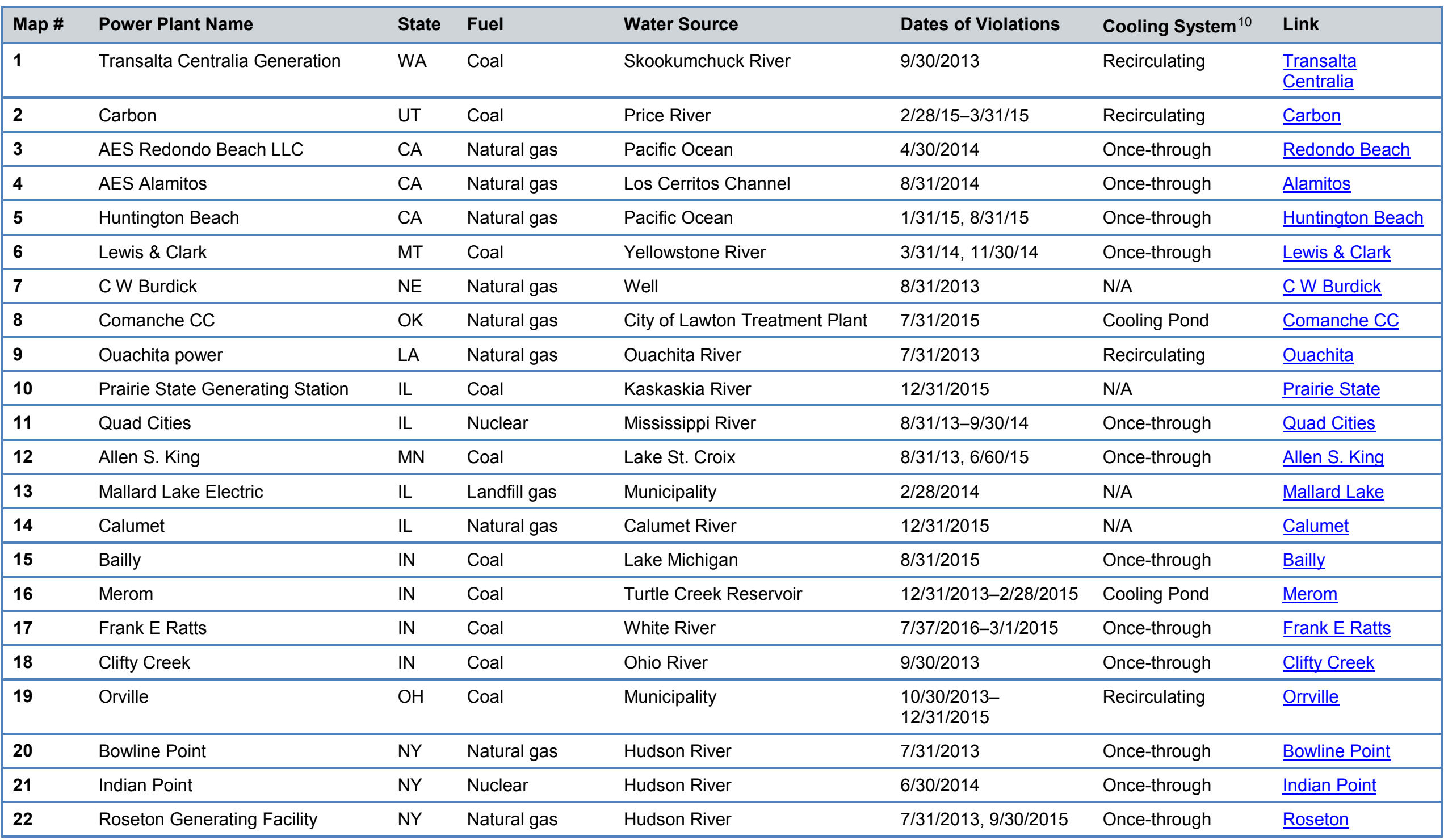

${ }^{10}$ Note: Cooling system data from Union of Concerned Scientists EW3 database. If plant was N/A, the cooling system type was not reported or the plant was not in the database. 


\begin{tabular}{|c|c|c|c|c|c|c|c|}
\hline Map \# & Power Plant Name & State & Fuel & Water Source & Dates of Violations & Cooling System ${ }^{10}$ & Link \\
\hline 23 & MM Taunton Energy & MA & Landfill gas & Taunton River & 1/1/2013-8/31/2015 & $\mathrm{N} / \mathrm{A}$ & $\begin{array}{l}\text { Taunton Municipal } \\
\text { Lighting }\end{array}$ \\
\hline 24 & Canal & MA & Residual fuel oil & Cape Cod Canal & 10/31/2013-8/31/2015 & Once-through & $\underline{\text { Canal }}$ \\
\hline 25 & Plainfield Renewable Energy & CT & Biomass & Quinebaug River & $12 / 31 / 2015$ & $N / A$ & Plainfield \\
\hline 26 & Bridgeport Energy Project & $\mathrm{CT}$ & Natural gas & Bridgeport Harbor & 7/31/2015-8/31/2015 & Recirculating & Bridgeport \\
\hline 27 & Northport & NY & Natural gas & Long Island Sound & $\begin{array}{l}9 / 30 / 13,8 / 31 / 14 \\
8 / 31 / 15\end{array}$ & Once-through & Northport \\
\hline 28 & $\begin{array}{l}\text { FirstEnergy Fort Martin Power } \\
\text { Station }\end{array}$ & WV & Coal & Monongahela River & $10 / 1 / 12-12 / 31 / 2015$ & Recirculating & $\frac{\text { Fort Martin Power }}{\text { Station }}$ \\
\hline 29 & Morgantown Energy Facility & WV & Coal & Monongahela River & $\begin{array}{l}8 / 31 / 14,7 / 31 / 15- \\
9 / 30 / 15\end{array}$ & Once-through & Morgantown \\
\hline 30 & Washington Energy Facility & $\mathrm{OH}$ & Natural gas & Muskingum River & $10 / 31 / 13,10 / 31 / 14$ & Recirculating & Washington \\
\hline 31 & Waterford Energy Facility & $\mathrm{OH}$ & Natural gas & Muskingum River & $\begin{array}{l}4 / 30 / 13,3 / 31 / 14 \\
4 / 30 / 14\end{array}$ & Recirculating & Waterford \\
\hline 32 & Robinson & SC & Nuclear & Black Creek & $10 / 31 / 2012$ & Cooling Pond & Robinson \\
\hline 33 & James E. Roger Energy Complex & NC & Coal & Broad River & 10/31/2013-6/30/2014 & Once-through & James E. Rogers \\
\hline 34 & Waiau & $\mathrm{HI}$ & Residual fuel oil & Pearl Harbor & $10 / 31 / 2014$ & Once-through & $\underline{\text { Waiau }}$ \\
\hline 35 & Eielson AFB Central Heat & AK & Coal, petroleum & Cooling ponds, three wells & $6 / 30 / 2013-9 / 30 / 15$ & Recirculating & Eielson AFB \\
\hline
\end{tabular}

